\title{
Productivity and Connectivity in Tropical Riverscapes of Northern Australia: Ecological Insights for Management.
}

\author{
NE Pettit ${ }^{1,7}$, RJ Naiman ${ }^{1,2}$, DM Warfe ${ }^{1,3}$, TD Jardine $^{4}$, MM Douglas $^{5}$, SE Bunn ${ }^{6}$ and PM Davies ${ }^{1}$ \\ ${ }^{1}$ Centre of Excellence in Natural Resource Management, The University of Western Australia, Albany, \\ Western Australia, 6330. \\ ${ }^{2}$ School of Aquatic and Fishery Sciences, University of Washington, Seattle 98195, USA. \\ ${ }^{3}$ School of Biological Sciences, University of Tasmania, Hobart, Tasmania, Australia 7001. \\ ${ }^{4}$ University of Saskatchewan, 44 Campus Drive, Saskatoon, SK, Canada S7N 5B3. \\ ${ }^{5}$ School of Earth and Environment, The University of Western Australia, Perth, Western Australia, \\ 6009. \\ ${ }^{6}$ Australian Rivers Institute, Griffith University, Nathan, Queensland, Australia 4111. \\ ${ }^{7}$ Current Address: School of Natural Sciences, Edith Cowan University, Joondalup, Western Australia \\ 6027.
}

\begin{abstract}
Flow regimes are fundamental to sustaining ecological characteristics of rivers worldwide, including their associated floodplains. Recent advances in understanding tropical riverfloodplain ecosystems suggest that a small set of basic ecological concepts underpins their biophysical characteristics, especially the high levels of productivity, biodiversity and natural resilience. The concepts relate to 1 ) river-specific flow patterns, 2) processes 'fuelled' by a complex of locally generated carbon and nutrients seasonally mixed with carbon and nutrients from floodplains and catchments, 3) seasonal movements of biota facilitated by flood regimes, 4) food webs and overall productivity sustained by hydrological connectivity, 5 ) fires in the wet/dry tropical floodplains and riparian zones being major consumers of carbon and a key factor in the subsequent redistribution of nutrients, and 6) riverfloodplains having inherent resilience to natural variability but only limited resilience to artificial modifications. Understanding these concepts is particularly timely in anticipating the effects of impending development that may affect tropical river-floodplains at the global scale. Australia, a region encompassing some of the last relatively undisturbed tropical riverine landscapes in the world, provides a valuable case study for understanding the productivity, diversity and resilience of tropical river-floodplain systems. However, significant knowledge gaps remain. Despite substantial recent advances in understanding, present knowledge of these highly complex tropical rivers is insufficient to predict many ecological responses to either human-generated or climate-related changes. The major research challenges identified herein (e.g., those related to food web structure, nutrient transfers, productivity, connectivity and resilience), if accomplished in the next decade, will offer substantial insights toward assessing and managing ecological changes associated with human alterations to rivers and their catchments.
\end{abstract}

Key Words: Connectivity, Rivers, Floodplains, Productivity, Biogeochemistry, Food Webs, Hydrology, Subsidies, Fluxes, Carbon, Nutrients 


\section{Introduction}

The fundamental importance of flow regimes for sustaining ecological processes in rivers and floodplains is well-established (Poff and others 1997; Tockner and others 2000; Junk and Wantzen 2004; Hoeinghaus and others 2007; Warfe and others 2011; Winemiller and others 2014). Fluvial processes and hydrological connections are superimposed on landscapes (i.e., riverscapes; Fausch and others 2002), and this 'layering' offers the potential to identify general patterns in riverine ecosystem function (Naiman and others 1987; Ward and Tockner 2001; Boulton and others 2008; Warfe and others 2011). Recent studies highlight the importance of flow predictability as a key factor determining whether floods act as a replenishing force, thereby enhancing productivity and heterogeneity, or a disturbing force altering physical templates and establishing new recovery trajectories (Lake and others 2006; Naiman and others 2008; Jardine and others 2015).

The tension between flow acting to replenish production or as a disturbing force is reflected in floodplain and food web characteristics as well as through pathways of spatial and temporal connectivity. It is widely acknowledged that seasonal inundation of floodplains underpins processes that contribute to river productivity (Junk and others 1989; McClain and others 2003; Junk and Wantzen 2004) and resilience (Parsons and others 2006; Parsons and others 2009; Townsend and Douglas 2014). Additionally, there is the aquatic transfer from seasonally inundated floodplains of nutrients and organic matter delivered in biogeochemical forms that support food web structure manifested as primary, secondary and tertiary productivity (Tockner and others 2000; Lewis and others 2000; Fisher and others 2004; Lewis 2008). Food webs, representing energy and nutrient exchange pathways among species, are tangible expressions of riverine productivity and physical connectivity among catchments, rivers and floodplains, as well as through time. Food webs convey an integration of ecosystem processes and biological community structure (McCann and Rooney 2009), providing a framework for understanding energy transfer and biogeochemical processes within aquatic systems (Winemiller 1996; Schindler and others 1997; Naiman and others 2012; Thompson and others 2012), and appear to be influenced by flow regime pattern.

Northern Australia represents one of the few relatively undisturbed tropical riverine landscapes in the world, where rivers are characterized by strong seasonality in flow regimes and high interannual variability in flood magnitude, frequency, duration and timing (Kennard and others 2010; Ward and others 2014; Jardine and others 2015; Pearson and others 2015). Rivers in northern Australia are especially informative because of their relatively intact state (e.g., limited flow regulation, low human population densities and little intensive development in the catchments; Stein and others 2002) and their resilience to widely variable environmental fluctuations (Pusey 2011). Inter-annual flood variability is largely a consequence of cyclonic events, the El Niño-Southern Oscillation (ENSO), Interdecadal Pacific Oscillation (IPO) and Indian Ocean Dipole (IOD) climatic variation (Hamilton and Gherke 2005; Hamilton 2010; Kennard and others 2010; Warfe and others 2011). The fluvial features of Australian tropical rivers (i.e., flooding and disconnection) drive patterns of 
connectivity and the heterogeneity, diversity, productivity and resilience of biota and biogeochemical processes. In many river systems, floodplains are not inundated across their full extent each year, meaning floodplain waterholes may not be reconnected in some years (Ward and others 2014); aquatic communities become divergent (Leigh and Sheldon 2009; Warfe and others 2013a; Pearson and others 2015) and consumers become highly dependent on locally produced resources (Jardine and others 2012a).

This article synthesizes recent advances in the ecological understanding of river-floodplain characteristics in tropical Australia, articulates six concepts to frame future research and management needs, identifies key knowledge gaps, and identifies similarities and contrasts with rivers from other tropical regions. We explore and discuss the merging of terrestrial and aquatic ecology with biogeochemistry to better understand river functions. Specifically, we examine the extent to which floodplains and associated riparian zones underpin the movement of aquatic biota, food webs and resilience in tropical Australia, and how these processes are driven by flood timing and lateral and longitudinal connectivity. Elsewhere, there have been significant advances in understanding linkages between aquatic biogeochemistry and ecology, particularly those between hydrology, nutrients and organic matter in aquatic food webs (Lewis and others 2001; Vanni 2002; Winemiller 2004; Power and others 2008; Hamilton 2010; Winemiller and others 2014), and those between landscape processes and river function (Rodriguez and Lewis 1997; Allan 2004; Hoeinghaus and others 2007). These and other recent advances provide the foundation for interpreting patterns observed in tropical northern Australia. This review is particularly timely for northern Australia, as well as for tropical South America, Africa and southeast Asia, in anticipating the effects of impending development of land and water resources in some of the last relatively undisturbed riverine landscapes in the world (Vörösmarty and others 2010; Finer and Jenkins 2013; Zarfl and others 2015).

\section{Physiographic Setting for Tropical Australia}

The physiography of tropical Australia is largely shaped by the ancient nature of the continent and its proximity to the equator (Latitude $11-19^{\circ} \mathrm{S}$, Fig. 1; Woinarski and others 2007; Ward and others 2011). The tropical region covers catchment areas that consist of the Timor Sea drainage, Gulf of Carpentaria drainage and the North-East (Coral Sea) drainage Divisions (Fig. 1). This area extends across northern Australia from Broome in the west to Townsville on the east coast, an area of over $1,200,400 \mathrm{~km}^{2}(16 \%$ of the Australian land mass and is equivalent to the area of South Africa). The northern Australian climate is chiefly influenced by an equatorial southern monsoon characterised by sharp seasonal rainfall, seasonally high temperatures $\left(>40^{\circ} \mathrm{C}\right)$ and high evaporation rates $(1200-3200 \mathrm{~mm}$ year $\left.{ }^{-1}\right)$. Rainfall is primarily generated by local convection storms, tropical cyclones or tropical depressions (monsoons), and is summer-dominated ( $>90 \%$ of rain falls between November and April). The North East drainage area of the north-eastern coast has a wet tropical climate to the north (Townsville to Cape York), where rainfall is much higher and streams are spatially short and perennial, merging into a wet-dry or dry tropical climate south of Townsville (Fig. 1, Pearson and others 2015). 
River flows reflect the climate's strong seasonality and high inter-annual variability (Kennard and others 2010). In the dry season most rivers become disconnected pools (Fig. 2) that are maintained to varying degrees by sub-surface and local groundwater flow. Only rivers connected to large groundwater aquifers, such as the Daly and Roper rivers in the Northern Territory, or those that flow east from the high rainfall uplands of NE Queensland, are perennial with sustained base flow throughout the dry season (Kennard and others 2010). The majority of rivers in northern Australia are naturally flowing, unimpeded by constructed barriers (Stein and others 2002). The Ord River in the Kimberley region of Western Australia and the Burdekin River in north east Queensland are the only large regulated rivers in the region with storage capacities of 35 million and 1.8 million $\mathrm{ML}$, respectively.

\section{Core Biophysical Concepts for Rivers in Australia's Tropics}

Australia's tropical riverscapes represent a model for river-floodplain ecosystem connectivity and how it functions in the absence of hydro-modification. A political focus (ca. 2000) on potential water resource development led to a proposal of five general hypotheses of food webs and ecosystem processes for northern Australian rivers (Douglas and others 2005) that, if correct, could inform research and management. These related to 1) seasonal hydrology as a strong driver of food web structure and ecosystem processes, 2) hydrological connectivity underpinning food web subsides, 3) food webs being largely algal-based, 4) a few common macroconsumers having a strong influence on benthic food webs, and 5) omnivory and short food chains being widespread. The hypotheses, based on minimal data, guided a 10+ year research program involving multiple institutions that focussed on hydrology, geomorphology, biogeochemistry, biodiversity, productivity, food web structure as well as socio-economic factors such as values, benefits and human dependence on freshwater resources (www.track.org.au; www.nerpnorthern.edu.au ). Major discoveries emerging from this research, as well as from concurrent research conducted by others, confirmed that seasonal hydrology and algal carbon are important for consumers (hypotheses 1,2,3), and that generalist/opportunistic consumers are common and widespread (hypothesis 5) and, therefore, influential in shaping the structure of aquatic food webs (hypotheses 4, 5). Based on the original hypotheses (Douglas and others 2005) as well as our published research and contemporary research advances by others, we identify six ecological concepts (Table 1) that offer an expanded conceptual framework for tropical rivers and suggest ongoing themes for further investigation.

\section{River flow attributes are a primary driver of spatial and temporal patterns in ecological processes.}

Whilst flow patterns may be highly predictable for some rivers, predictability is spatially variable across northern Australia (Kennard and others 2010) and temporally variable within a year as flows alternate between the wet and dry seasons (Fig. 2). Flow characteristics are reflected in ecological productivity patterns, in the inherent diversity of organisms and processes, and ultimately in ecosystem resilience (Jardine and others 2015). Some 
floodplains, for example the floodplains of the Alligator rivers in Kakadu National Park (KNP), can remain inundated for over six months, supporting high levels of aquatic primary production and often large waterbird populations (Bayliss and Yeomans 1990; Pettit and others 2011; Warfe and others 2011). In contrast, many other floodplains are inundated for only weeks or days at a time, and often the inundation is rapid, turbid, and operates as sheet flow over an essentially terrestrial landscape (Ward and others 2013). These systems are characterized by a 'flush' in terrestrial primary production post-flood while aquatic production is short-lived and largely limited to remaining waterholes following flood recession (Pettit and others 2012a). Such spatial and temporal variability leads to highly variable aquatic connectivity with considerable influences on the provision of habitat (Wasson and others 2010; Pettit and others 2013), biotic assemblages (Pettit and others 2001; Leigh and Sheldon 2009; Warfe and others 2013a), population dynamics (StewartKoster and others 2011; Ward and others 2014; Jardine and others 2015), biogeochemical processes (Hamilton 2010) and the use of aquatic resources by local Indigenous communities (Jackson and others 2012).

The high variation in timing and predictability of inundation and expression of stream physical characteristics (such as geomorphology and habitat) creates highly complex interactions in biogeochemical processes and fluxes (Ward and others 1999). Flooding exerts selective pressures on river biota while at the same time enhancing productivity and diversity. The consequences of the interaction between these two effects can be understood through the pattern of timing and magnitude of flood events (rhythm; Winemiller and others 2014; Jardine and others 2015). For instance, flooding is a massive alteration of connectivity pathways (Fig. 2), so that not only does an ecosystem expand and reassemble, but organisms need to renegotiate the newly configured physical pathways of connection. Where flow is highly rhythmic, biota are better able to adapt to the cycle of flooding and drought and, as well, biodiversity and annual riparian productivity are higher than for rivers with an unpredictable flood regime (Jardine and others 2015). This suggests that there is more to the relationship between flows and ecology than our original understanding of ecological response as a function of flood events and annual discharge (Junk and others 1989; Loneragan and Bunn 1999).

\section{Carbon and nutrient inputs from the floodplain and catchment, modified by} biogeochemical processes, may provide important additions to instream productivity.

The extent to which riparian zones and floodplains supply carbon and nutrients to heterotrophic microbes and primary producers in rivers as well as the dominant sources, remains uncertain. Though aquatic consumers appear to be primarily supported by algal carbon (see Concept 4 below) and the ${ }^{15} \mathrm{~N}$ depleted stable nitrogen isotope values of algae suggest $\mathrm{N}$-fixation in some northern rivers (Davies and others 2008), sediments and terrestrially derived organic matter also contribute nutrients to support aquatic primary production (McIntyre and others 2009, Fellman and others 2013). In general, the majority of nutrients entering these river systems from the floodplain and riparian areas (in particular $\mathrm{P}$ ) are associated with sediment inputs. In addition, for these low $\mathrm{N}$ systems the largest part of 
the bioavailable $\mathrm{N}$ input is likely to come from $\mathrm{N}$-fixation by both algal and fish biomass. However, although terrestrial organic matter (OM) represents a relatively small source of nutrients, we suggest it may be locally important in stimulating algal productivity and thus influencing the metazoan food web, particularly in disconnected pools in intermittent streams (Blanchette and others 2014; Siebers and others 2016). While our understanding of energy sources has improved markedly over the last decade, nutrient sources and sinks represent a considerable knowledge gap (Table 1). Indications are that there may be close river/floodplain biogeochemical connectivity in the input of allochthonous dissolved organic carbon (DOC) and available $\mathrm{N}$ and $\mathrm{P}$ in streams of increasing size in the Kimberley region (Fellman and others 2013). However whether this is true more generally requires further investigation of other river systems across northern Australia.

The intermittent flow regimes of most tropical Australian rivers means that rapid transport of carbon is effectively prevented during the dry season. This is when riparian litterfall is likely to be at its greatest. Longitudinal exchange throughout the river network is likely concentrated around transitional flow events between the wet and dry seasons and the peak wet season flows. Both terrestrial and in-stream organic matter delivered downstream in early season storm-flows occasionally contribute to a short period of poorer water quality (Townsend and others 1992). Such flows can also move large amounts of sediment via channel erosion and gullying (Wasson and others 2010) and has been shown in models of flow-related water quality for the Great Barrier Reef catchments (Davis and others 2016). This movement of sediments will also provide a significant nutrients and carbon to downstream reaches (Garzon-Garcia and others 2015). With increasing time since flooding, controls on stream biogeochemical processes transition from predominantly hydrological to more local scale environmental controls.

Two related factors are especially relevant: sources and fluxes of detritus and nutrient biogeochemistry:

A) Sources and fluxes of carbon. Large quantities of carbon as particulate organic matter from seasonal riparian litterfall or overland flow and from channel or gully erosion are carried downstream during the wet season. As stream size increases and modern, terrestrially derived DOC accumulates, bioavailability decreases because of the refractory nature of this latter source (Fellman and others 2014). The input of allochthonous leaf litter may influence in-stream primary production through indirect priming effects via increased mineralization of recalcitrant OM (Guenet and others 2010). This is generally in the presence of labile carbon inputs, as mediated by microbial action (Siebers and others 2015). In some headwater streams, old bioavailable DOC originating in groundwater is an important source of labile carbon, but due to its labile nature there is rapid uptake by microorganisms (Fellman and others 2014).

The species-specific characteristics of allochthonous material (i.e. availability, chemical and nutrient composition), as well as the diversity of aquatic micro-organisms in receiving environments, play significant roles in the transformation and availability of detritus to consumers (Pettit and others 2012b). The chemical nature of DOC determines its fate; whether it remains stored in the system, undergoes photochemical or physical degradation 
or is transformed into dissolved inorganic carbon (DIC) via microbial degradation. Many riparian plants common to northern Australian rivers in the Myrtaceae family, such as Melaleuca spp, produce leaves high in tannins and other volatile compounds that are not readily decomposed (Fig. 3; Coley and Barone 1996). Decomposition requires high UV light and specialist microorganisms to facilitate breakdown into chemical forms that are available to stream biota (Fellman and others 2013; Lambert and others 2015).

B) Dynamics of nutrient biogeochemistry. Concentrations of stream water N and P are consistently low across northern rivers (Brodie and Mitchell 2005; Townsend and others 2012), with the highest concentrations occurring in waterholes at the end of the dry season (e.g. Pettit and others 2012a). With the onset of the first wet season flows these nutrients are redistributed across floodplains where concentrations rapidly decline through dilution and uptake (e.g. Hart and others 1987) or exported to the sea.

Despite an overall low nutrient environment, in-stream production rates of $100-1,230 \mathrm{mg} C$ $\mathrm{m}^{-2}$ day $^{-1}$ have been recorded in northern Australian rivers (Davies and others 2008, Townsend and others 2008, Hunt and others 2012, Burford and others 2011). This suggests that, together with $\mathrm{N}$ fixation, rapid bacterial degradation of photosynthetically-produced DOC releases bound nutrients for primary production (Townsend and others 2011). The ancient and highly weathered geology of the northern Australian landscape may explain low nutrient concentrations and the adaptations of algae to grow with limited nutrients. Indirect terrestrial-aquatic linkages may be a critical but poorly quantified component of river-floodplain ecosystems, especially during the dry season when hydrologic inputs of $\mathrm{N}$ and $\mathrm{P}$ are low and at these times, a sizeable fraction of $\mathrm{N}$ and $\mathrm{P}$ may be in fish biomass (Burford and others 2008). The elemental stoichiometry of many tropical streams is linked to the low availability of $\mathrm{P}$. This likely leads to higher internal recycling of nutrients within biofilms or sediments (Mulholland and others 1995; Kufel and Kufel 2002) but, admittedly, it is not yet clear if this process is broadly expressed in northern Australia.

The large plant biomass on many riparian and floodplain surfaces (Fig. 3; e.g., 45-60 t ha-1; Magela Creek floodplain; Pettit and others 2011) may also account for nutrient cycling and low nutrient concentrations in floodplain waters and sediments (Finlayson 2005). On the Magela Creek floodplain, the highest total $\mathrm{N}$ concentrations are found at the floodplain inlet in the first wet season flows but the spike in $\mathrm{N}$ is not detected at the outlet (Hart and others 1987). Although denitrification processes are likely to be the main driver, $\mathrm{N}$ sequestration across the floodplain, primarily through the growth of epiphytic algae (Pettit and others 2016) and macrophytes (Finlayson 1991) also may be significant. Recycled plant material also may be an important source of soil nutrients on the floodplain with grass detritus containing substantially higher levels of nutrients $(\mathrm{N}, \mathrm{P}, \mathrm{K})$ than concentrations in the inputs of water from KNP streams (Northern Territory) to the floodplain (Finlayson 1991). Nutrient sequestration of $4 \mathrm{t}$ total phosphorus, $9 \mathrm{t}$ nitrogen oxides (NOx-N) and $14 \mathrm{t}$ ammonium $\left(\mathrm{NH}_{4}\right.$ $-\mathrm{N}$ ) is a significant part of the phosphorus and nitrogen accumulated in soils and aquatic plants growing on the floodplain (Pettit and others 2011). Additional nutrients from sediments are re-cycled through micro-organisms, algae and macrophytes but little is currently known about rates or specific mechanisms. How much of this is then lost to the atmosphere by fire remains an important research question (see Concept 5). 


\section{The movement of biota is facilitated by hydrological connectivity}

Extensive movement of biota (either seasonal or long-term population exchanges) across riverscapes results in relatively cosmopolitan distributions of some species (Pusey and others 2011) and predictable assemblages across northern Australia (Warfe and others 2013a). While these observations may be partly due to insufficient taxonomic and limited genetic knowledge of cryptic fish species (e.g., Cook and others 2011) and macroinvertebrates (Garcia and others 2011), they suggest regular hydrological connectivity periodically removes or minimizes dispersal barriers, resulting in population replenishment, generalist feeding strategies (Leigh and others 2010; Pusey and others 2011) and relatively stable food web structures (Warfe and others 2013b).

Considerable lateral exchange of resources and biota occurs between rivers and their floodplains during the wet season. Animals exhibiting lateral movement in response to flooding include waterbirds, crocodiles (Crocodylus porosus), fish and crustaceans (Fig. 4; Whitehead and Saalfeld 2000; Pettit and others 2011; Warfe and others 2011), and movement occurs even if floodplains are inundated for relatively short periods (Jardine and others 2012b). Highly productive aquatic macrophytes and grasses support recruitment and the fledglings of waterbirds (Bayliss and Yeomans 1990) and crocodiles, even though some crocodile nests risk washout during initial inundation (Webb and others 1977). Reliance of local Indigenous communities on key floodplain biota (e.g., long-necked turtle Chelodina rugusa and lotus lily Nelumbo nucifera) strengthens over the wet season as access to mainstem river resources weaken proportionately (Jackson and others 2012). Small fish and invertebrates graze on periphytic algae living on plants submerged by wet season flooding and the return of these animals to permanent water can support a large fraction of the diet of larger fish and crocodiles in the rivers (Jardine and others 2012b). These movements suggest a substantial energy subsidy from the floodplain to other parts of the river network with a transition from the wet into the dry season, particularly where flow timing and magnitude are relatively predictable (Jardine and others 2015). Thus, the apparent tension between the disturbance and replenishment role of floods (Lake and others 2006) potentially may be seen in the degree of variability among food webs, communities, populations and life histories as regulated by rhythmic connectivity (Jardine and others 2015).

Longitudinal connectivity also provides for the extensive movements of biota. Over a third of fish species in Australia's tropical rivers migrate to the estuary during their life history, about another third are "estuarine vagrants" often found hundreds of kilometres upstream, and many remaining species (e.g., Plotosidae catfish) use periods of hydrological reconnection to move into tributaries and spawn (Pusey and others 2011). Movement patterns are likely to vary spatially, depending on flow regime and the location of refugia (Pusey and others 2011). In small rivers, the upstream movement of plotosid catfish and Terapontidae grunters (Fig. 4) peaks during the dry to wet transition, and downstream movement peaks during the wet to dry transition, particularly in intermittent streams (Bishop and others 1986; D.M. Warfe and N.E. Pettit, unpublished data). In contrast, on Magela Creek, plotosids 
and terapontids generally move downstream (from permanent refugia upstream) during the dry to wet transition and then move back upstream to permanent refugia during the wet to dry transition (Bishop and others 1986).

Connectivity is paramount in shaping riverine community structure and trophic dynamics as food web links are made and broken across the land-water interface in response to flooding (Naiman and others 2008; Jardine and others 2015). Across northern Australia, invertebrate assemblages differ according to hydrologic connectivity (Leigh and Sheldon 2009; Warfe and others 2013a) and biomass at many locations is dominated by migratory decapod crustaceans (e.g., prawns, Macrobrachium sp; crayfish, Cherax sp; Jardine and others 2013). Fish diversity ranges from $<10$ species in basins with shorter and more irregular flood periods to $>50$ species in larger, more connected basins (Jardine and others 2015), and food web complexity varies accordingly. Some hydrological periods (late dry season) or basins with low connectivity have tight internal ecological links and weak external links (Jardine and others 2012a; Blanchette and others 2014), whereas those with extended connectivity have relatively weak internal links and strong external links.

\section{Primary and secondary production relies on connectivity, and sustains food webs}

The source and quality of carbon that support aquatic consumers vary within river and floodplain ecosystems depending on the variability of environmental conditions through space and time. Periphyton are often the dominant carbon source for large consumers (Douglas and others 2005) both in waterholes (Jardine and others 2013) and on floodplains (Jardine and others 2012b; SE Bunn, unpublished data). Other organic matter sources can make considerable contributions to organisms lower on the food chain; however, spatial and temporal variability is large (Leigh and others 2010; Hunt and others 2012; Pettit and others 2012b; Fellman and others 2013; Blanchette and others 2014). Leaf litter supplements invertebrate diets, as has been demonstrated for Australian wet tropics headwater streams (Pearson and Connolly 2000) and waterholes in intermittent streams of the Gulf of Carpentaria drainage (Leigh and others 2010), but the low quality of this material is a major dietary constraint and contributions to animals via this pathway likely arise from 'leakage' from the microbial loop rather than from direct consumption (Pettit and others 2012b; Fellman and others 2013). Nevertheless, observations that algae are deemed the dominant food source for metazoans have been reported from a variety of tropical systems (Lewis and others 2001; Brito and others 2006; Lau and others 2009). This is most evident in larger consumers, such as the predatory fish barramundi (Lates calcarifer), where isotopic evidence indicates a strong link to algal sources of carbon (Jardine and others 2012b; Jardine and others 2013).

Plankton appear to be unimportant in waterhole food webs except for small pelagic consumers (Jardine and others 2013). Similarly, planktonic production on floodplains is generally limited in basins with short-duration floods (e.g., Mitchell River) where floodplain water column Chlorophyll $a$ is $<2 \mathrm{ug} / \mathrm{L}$ (TD Jardine, unpublished). While planktonic production may be substantial in long-duration floods such as those at KNP (M.F. Adame and others, in review), there is little evidence that plankton features strongly in the diets of 
floodplain consumers (SE Bunn, unpublished data). Given these observations, bottom-up effects are likely to occur via periphyton (Garcia and others 2015a). Many Australian tropical rivers are oligotrophic and either $\mathrm{N}$-limited or $\mathrm{N}$ and $\mathrm{P}$ co-limited (Faggotter and others 2013; Garcia and others 2015a; TD Jardine, unpublished data). Light limitation also can be important in lower river reaches (Burford and others 2011) with high turbidity during floods ( > 2000 NTU; Flinders River, TD Jardine, unpublished data).

Despite evidence elsewhere for longer maximum food chain lengths in more productive rivers (Takimoto and Post 2013), for Australian tropical rivers it was initially considered that food chain length would be relatively short (Douglas and others 2005). This has been supported to some extent as large predators such as barramundi and crocodile (Hanson and others 2015; T. D. Jardine and others in review) can feed 'low' in the food chain because of the presence of abundant, large-bodied herbivorous prey such as mullet (Liza spp) and bony bream (Nematalosa erebi; c.f. Layman and others 2005). Retreat of these predatory species into dry season refuges mixes them with resident biota where there are parallel short food chains terminating at high trophic levels but with relatively small bodied species such as terapontid grunters (Rayner and others 2009; Warfe and others 2013b). As a result of the mixing of itinerant and resident biota, maximum food chain lengths in these systems are similar to those in other tropical freshwater systems outside Australia (Rayner and others 2010; Jardine and others 2011), despite the largest predators feeding low on the food chain (Jardine 2016 in press).

Larger organisms have larger home ranges and consume prey from a wider range of habitats (McCann and others 2005; Hanson and others 2015, Jardine and others in review), making food webs highly scale dependent. For instance, the crocodile food web must include the entire catchment, while small fishes and invertebrates feed at the mesohabitat scale or smaller (Jardine and others in review). This mix of spatial scales affects different species as habitat expands and contracts confounding attempts to link food web characteristics to local environmental factors (Warfe and others 2013b). Food web linkages across habitat boundaries and between ecosystems are therefore likely to be important, but these are scale-dependent. Unfortunately, we are only beginning to understand how the habitat-tohabitat food web linkages and biogeochemical connectivity (discussed in the previous sections) are related to aquatic food web assemblages and overall ecological productivity.

\section{Fire is a major consumer of carbon and a contributor to nutrient dynamics on floodplains}

Unlike wetter African and neotropical systems where senescent primary production left by the recession of floodwaters is consumed by grazers and microbial activity (Winemiller 1996), it appears that a large proportion of the residual production on Australia's wet/dry tropical floodplains is consumed by fire (Pettit and others 2011). Much of this organic matter, therefore, does not find its way the river in a traditional sense. While floodplain and riparian fires in tropical areas have not been extensively investigated (Table 1; but see Douglas and others 2015), fire is likely to have particularly important effects on biogeochemical processing (Pettit and Naiman 2007). On Australian tropical floodplains dry season fires are a significant "consumer" of carbon and nutrients (Pettit and others 2011), 
with $26 \%$ of floodplains within KNP burnt between 1996 and 2000 (Edwards and others 2003). The estimated fire return interval on the Magela floodplain within KNP (1980 to 2006 ) is five years, contrasting with two years for the adjacent savanna woodland (Bayliss and others 2006). Therefore, the more frequent savanna fires can have greater impact as they cause the loss of ground cover and increased surface erosion, which can ultimately result in sediment/turbidity spikes in river-floodplain waters. Most fires, particularly on floodplains, occur late in the dry season and are generally high intensity as fuel is drier, loads are greater and severe fire weather conditions prevail.

The impact of such fires is the production of nutrient-rich ash and loss of the litter layer and grass cover (Cook 1994). Following savanna fires, $\sim 7 \%$ of fine fuels remain as charred fragments which contain $40-70 \%$ of $\mathrm{P}, \mathrm{K}, \mathrm{Ca}$ and $8 \% \mathrm{~N}$ and $\mathrm{S}$ (Cook 2003). However, $\mathrm{N}$ loss in a fire $\left(1.4-2 \mathrm{~kg} \mathrm{ha}^{-1} \mathrm{yr}^{-1}\right)$ is the only nutrient to exceed gains from rainfall or dry deposition (Cook 2003). Fixation of $\mathrm{N}$ by cyanobacteria in floodplain soils may therefore be particularly important after fire; $\mathrm{N}$-fixing plants and cyanobacteria are crucial for the replacement of soil N (Cook 2003).

Black carbon (i.e., charcoal), produced by incomplete combustion of plant material in wildfires, is found in many soils and floodplain sediments (Goldberg 1985). Charcoal can raise soil $\mathrm{pH}$, improve air circulation and increase the soil's ability to retain water and nutrients. Once added, the benefits of charcoal through adding carbon and nutrients and improving water holding capacity, continue for years. For instance, burning of forest that adds black carbon to infertile soils in the Amazon basin has created small areas of very fertile soils characterised by relatively high levels of organic matter, N and P (Schmidt and Noack 2000). Conversely, burning of biomass has been suggested as another important contributor to potentially refractory organic- $\mathrm{N}$ in soils (Cook 2003).

Increased burning of floodplains and associated rainforests and paperbark (Melaleuca spp) forests has been reported for northern Australia (Russell-Smith and others 1997). For floodplains in KNP this may be related to the eradication of water buffalo (Bubalus bubalis) and the subsequent increase in aboveground grass biomass (McGregor and others 2010), particularly the establishment of invasive Para grass (Urochloa mutica) in many floodplain areas. As well, there is evidence of positive feedback between fires and grass invasion in other northern Australian habitats (Butler and Fairfax 2003; Rossiter and others 2003).

Fire in riparia and floodplains reduce inputs of detritus and increase ash input to aquatic environments (Douglas and others 2015). Fires also affect ecosystem complexity by creating open patches that increase aquatic productivity during the flooded phase. In recent times there has been a willingness to re-introduce traditional fire management to areas such as the KNP wetlands (MacGregor and others 2010). These traditional patch burning practices have the potential to enhance biodiversity as well as the cultural importance of these wetlands to local Aboriginal people. Effective burning for natural resource management and for culture requires the cooperation of western science and traditional Aboriginal expert knowledge that has developed over generations (McGregor and others 2010). Intensive fire management for tropical floodplains and rivers is needed to develop fine-scale habitat 
patchiness so that the multiple objectives of $C$ sequestration, emissions abatement and biodiversity conservation can be achieved (Richards and others 2011).

\section{Through adaptation to changing ecological conditions, river-floodplains have inherent resilience to natural variability but only limited resilience to artificial modifications}

Ecological resilience is measured as the magnitude of change that a system can absorb before the system re-assembles into another state, often with different controlling variables and processes (Gunderson and Holling 2002; Gunderson and others 2002; Scheffer and others 2003). The focus of ecological resilience is on maintaining key ecosystem functions (Gunderson and others 2002), such as biogeochemical processes or recruitment events. Properties that confer general resilience include diversity of species, habitats and processes, as well as linkages between these components and the various feedbacks that are at play (Table 1; Dambacher and others 2002; Walker and Salt 2006).

In the Australian wet-dry tropics the dynamics of river and floodplain ecosystems are to a large extent determined by high variability and low predictability in seasonal flooding and drought. The ecological systems change rapidly but then restructure to similar conditions after a major disturbance. Annual floods provide natural change that displaces biota, alters water quality and triggers regrowth of aquatic plants before ultimately returning to a state with characteristics similar to those preceding the flood (Pettit and Froend 2001; Pettit and others 2012a). Variability in flows is likely to be important in conferring resilience on river systems by enabling a range of biological and physical characteristics to interact with the life history traits of biota (Naiman and others 2008; Davies 2010). This variation in the physical environment, such as shape and depth of waterholes and the type and extent of riparian vegetation, also contributes to resilience in that there is a diversity of biophysical ecosystem functions (Colloff and Baldwin 2010; Pettit and others 2012a). The importance of maintaining flow connectivity between floodplain waterholes and the river, together with sufficient variability in the flow regime (Naiman and others 2008; Opperman and others 2010), allows the seasonal resetting of conditions that maintain resilience. There is evidence from a South African savannah river of floods leaving a heterogeneous imprint on the riparian ecosystem, resulting in multiple trajectories of ecological responses, indicating the longer term resilience of the river to natural floods (Table 1; Pettit and Naiman 2005; Parsons and others 2006). Unfortunately, there is little direct evidence of a similar nature for tropical northern Australia (see Pettit and others 2012a). Since multiple consumers (e.g., Magpie geese, Anseranas semipalmata; Bayliss and Yeoman 1990) take advantage of the connectivity provided by inundation and move onto the floodplain, and later switch (at low water) to consuming macrophytes and allochthonous carbon sources, this demonstrates species-scale resilience to flooding through an ability to adapt to changing conditions. Resilience is also seen through the persistence of benthic algal communities in smaller upstream tributary refuges during scouring wet season flows. Algae from these refuges recolonise the main channel when floodwaters recede (Townsend and Douglas 2014).

Like other types of natural ecosystems, Australian tropical river landscapes are characterized by episodic change, patchiness, variability and expression of processes at multiple scales 
(Warfe and others 2011; Jardine and others 2015). In essence, they can have multiple stable states, some of which have high resilience (Gunderson and Holling 2002). For instance, biophysical heterogeneity and temporal variation in precipitation, flow and flooding operate as selective pressures on biota and result in a broad range of life history traits across tropical Australia as well as within catchments (Bunn and Arthington 2002; Lytle and Poff 2004). This broad range of traits maintains greater functional diversity, allowing a greater range of biota to 'share' the same system and thereby provides a greater scope for sustaining biodiversity and ecosystem resilience (Poff and Allan 1995; Poff and others 1997; Ward and others 1999; Naiman and others 2008; McCann and Rooney, 2009).

There are a number of traits that enable plants to cope with historic riparian and floodplain conditions (Catford and Jansson 2014). These include traits that allow tolerating or avoiding anoxia and enabling underwater photosynthesis, traits that confer resistance and resilience to hydraulic disturbance, and attributes that facilitate dispersal, such as floating propagules (Naiman and Décamps 1997). Nevertheless, the vulnerability of riparian and floodplain ecosystems to emerging conditions, such as climate change, is potentially problematic. Their potential exposure, sensitivity, and the adaptive capacity of key biotic components and processes, as well as the potential for invasion by non-native species are all responsive to environmental change (Catford and others 2013). For example on the floodplains of KNP the invasive Para grass has the potential to reduce the resilience of the floodplain ecosystem through directly reducing diversity of plants species and indirectly by altering fire regimes (Douglas and O'Connor 2004). Also, this C4 species is not utilised in the floodplain aquatic food web (Douglas and others 2005) and the dense growth and vertical dimensions of Para grass is likely to also reduce algae production (Pettit and others 2016), a key food source for secondary production on the floodplain.

Physical changes such as trampling and grazing by livestock and other introduced mammals, or widespread hydrological alterations, have the potential to reduce system resilience and cause regime shifts in riparian and floodplain conditions. Feral water buffalo were introduced to the Alligator rivers area in Northern Australia in the early 1800s and their numbers increased rapidly causing widespread destruction of floodplain habitats and loss of species and ecosystem resilience (Skeat and others 1996; Petty and others 2007). An extensive eradication program substantially reduced buffalo numbers and, in combination with changed fire regimes, led to large increases in native grass Hymenachne acutigluma in wetter areas and exotic Para grass in drier areas, where it replaced native wild rice (Oryza spp.), an important food plant for magpie geese (Ferdinands and others 2005). This suggests that the KNP floodplains, for example, were resilient (particularly in the wetter areas) to widespread trampling and grazing by water buffalo. Although the vegetation was denuded across much of the floodplains, within a few years of the buffalo removal the native plants recolonised and no species were actually lost (Petty and others 2007). Residual populations of seed banks persisted long enough for recolonisation to occur once grazing pressure was removed, suggesting low resistance but high resilience to grazing.

In contrast, projected climate related sea level rise is likely to lead to the crossing of a major abiotic threshold for low elevation floodplains as inundation by saltwater and hydrologic alterations following from saltwater intrusion will result in fundamental changes. It is 
expected that the new saline environment will be recolonised by salt tolerant plants such as mangroves as freshwater vegetation dies out (Catford and others 2013; Bayliss and others 2016). Therefore while these floodplains may be resilient to other disturbances due to a long history of adaptation to flooding, fire and grazing, it would appear that they would be very unlikely to maintain resilience to rapid sea level rises.

Australian tropical floodplain rivers operate within a range of natural flow regime variabilities, which can be large and unpredictable (e.g., Flinders River) or relatively less variable and more predictable (e.g., the Alligator rivers of KNP; Ward and others 2013; Ward and others 2014). However, if flow variability is extreme (or much reduced) it can have negative effects on biodiversity and productivity (Jardine and others 2015) and ecosystem resilience (Lake and others 2007; Naiman and others 2008). Biophysical alterations, other than the natural flood regime, that cause changes to timing and decreases in magnitude, duration or predictability of flood events, are likely to be detrimental and severely 'test' the resilience of river systems and possibly lead to a change of state. For example, the Ord River in the Kimberley region of northern Australia was dammed in 1963 and a larger dam constructed $50 \mathrm{~km}$ upstream in 1973. River regulation in the ensuing 40 years has produced large ecological changes throughout the downstream river system as the natural highly variable flow regime has been radically changed (Doupe and Pettit 2002). While there has been some recruitment and increased density of riparian plants in a much narrower riparian zone, restricted to areas close to the river flows, there has been a significant alteration in the age class structure and the spatial distribution of the riparian trees (Doupe and Pettit 2002). This is likely to reduce resilience of the riparian forest to large disturbances such large floods or fire. As well, the impoundment has had a pronounced impact on the life histories of many fish species and dramatically reduced the distribution (and the abundance) of barramundi to about one-quarter of its former range in the river (Doupe and Pettit 2002).

Knowledge of riverine and riparian attributes that confer stability and resilience is critically important in management, particularly in the face of possible combined stressors of invasive animals, weeds, water resource development, and climate change (Pusey 2011). Maintaining or restoring natural flow regimes and their natural variability is thus fundamental to the ecology of river systems (Naiman and others 2008; Warfe and others 2011) and therefore is a primary goal of environmental flow regulations designed to maintain ecosystem resilience (Davies and others 2014). In a practical sense, this entails maintaining high biodiversity, natural habitat dynamics and biophysical variability over the long term, which in turn supports ecosystem-scale characteristics underpinning productivity and resilience (McCann and Rooney 2009). Unfortunately, understanding specific ecosystem characteristics and processes conferring resilience remain poorly documented for Australian tropical rivers. In particular, investigations are needed that span many seasons in order to capture the true natural variability and thereby provide insights into understanding and managing specific characteristics and processes imparting resilience to these riverine ecosystems.

\section{Understanding the Ecological Integrity of Natural Tropical Rivers}


Many tropical rivers, including those in South America, Africa and Asia, have sustained seasonal flood pulses driven by annual precipitation patterns (e.g., Junk and others 1989; Dudgeon 2000; McClain and others 2014; Winemiller and others 2014). These changes in flow alter concentrations of dissolved nutrients, the fates of carbon, aquatic primary production, densities of aquatic organisms, and the strength of top-down effects of animals on basal resources that shift as the annual flood pulse progresses. This emphasizes the predictable and gradual changes in consumer-resource interactions and biogeochemistry associated with the seasonal flood pulse in tropical rivers around the world, which exhibit many similarities to tropical rivers in Australia (Table 1; Fig. 5; Jardine and others 2015; Davis and others 2016). These biogeochemical and biotic interactions act within and across scales from micro-surfaces within a pool up to the macro-scale of entire catchments.

The sum of growing knowledge of tropical rivers in Australia and elsewhere aligns well with the recently developed River Wave Concept (RWC; Humphries and others 2014). In this river ecosystem model, the components of a wave (trough, crest, ascending and descending limbs) correspond to seasonal changes in river flow that have consequent effects on ecological processes. The RWC integrates the three well-established models of riverine function (e.g., the River Continuum Concept - RCC, Vannote and others 1980; the Flood Pulse Concept - FPC, Junk and others 1989; and the Riverine Productivity Model - RPM; Thorp and others 2006) with each model describing processes corresponding to different wave components. This provides an intuitive conceptual overview for river-floodplain ecosystems and how their structure and function are regulated by hydrological connectivity. For example, the disconnection of many river and floodplain aquatic habitats during the dry season correspond to the river wave trough, where local autochthonous production, local allochthonous inputs, decomposition and assimilation predominate, as described by the riverine productivity model (Thorp and others 2006) and as observed in northern Australia (Pettit and others 2011; Jardine and others 2013; Pettit and others 2012b). On the ascending and descending limbs of the river wave, longitudinal transport of energy and materials are emphasized, as elaborated in the RCC (Vannote and others 1980). In northern Australian rivers, the transition between the wet and the dry seasons is a key period for material transport (Townsend and others 1992; Schult and others 2007), biotic movement (Jenkins and Forbes 1985; Pusey and others 2011; Warfe and others 2011) and primary production (Pettit and others 2011; Garcia and others 2015b). At this time large consumers are likely to acquire most of their annual growth from feeding at seasonally-available specific locations. The crest of the river wave corresponds to sustained flooding and inundation that facilitates lateral exchanges of energy and materials across the riparian and floodplain zones. This period is well-described in the FPC (Junk and others 1989) and is widely observed in northern Australia (Jardine and others 2012b; Jardine and others 2015).

\section{Research Challenges and Management Implications}

The functioning of tropical river systems (and river systems in general) is characterized by an unusual complexity of ecological processes as well as the importance of river-

floodplain/riparian linkages (Table 1, Fig. 5). These affect key biogeochemical processes that underpin nutrient availability and primary production as well as how connectivity shapes 
aquatic food webs and diversity. As noted by Marcarelli and others (2011), our limited understanding of linkages between biogeochemistry and food web processes is a key knowledge gap. To achieve better understanding of how and when these processes operate, cross-disciplinary studies are required to merge terrestrial and aquatic ecology with biogeochemistry and hydrology. For instance, despite a general acknowledgement of the critical role of algae as a basal carbon source in tropical rivers and floodplains, there is little documented knowledge about the dynamics of these primary producers, particularly diversity, production, turnover rates or nutrient dynamics (Townsend and Padovan 2005; Ganf and Rea 2007; Townsend and Douglas 2014). A topic not well understood for tropical rivers is the role of terrestrially-derived carbon and nutrients (via subsurface as well as overland flows), especially their role in stimulating in-stream and floodplain production (Fellman and others 2013; Fellman and others 2014). Documenting the mechanics and dynamics of these linkages is a primary challenge for future research. This includes a fuller understanding of the importance of the variability of flows and connectivity as well as the consequent range of biogeochemical and biotic responses.

Although there are some tropical rivers that still have largely unmodified flow regimes, this is rapidly changing. For example, in Andean tributaries of the Amazon River, 151 new dams over $2 \mathrm{MW}$ are planned over the next 20 years (Finer and Jenkins 2013). This will result in a significant loss in connectivity between headwaters and the lowland reaches of the Amazon which relies on headwater streams for carbon and nutrient supplies (McClain and Naiman 2008). This challenge is also facing northern Australian rivers, with a strong political interest in development, particularly of water resources (http://industry.gov.au/ONA/WhitePaper/index.html). A major consequence of water extraction in Australian systems is likely to be reduced dry season baseflows in perennial rivers. A reduction in baseflow has the potential to reduce the availability of critical flowsensitive habitats, break vital river/floodplain seasonal re-connectivity, and reduce overall ecosystem complexity (Warfe and others 2011; King and others 2015). Increased flows due to river regulation or dewatering from mining operations are also likely to have large ecological effects, especially the change from ephemeral to permanent flow regimes (Doupe and Pettit 2002; Fellman and others 2011). Therefore environmental flow assessment needs to include fundamental ecosystem processes related to the connectivity between the river and the floodplain such as biogeochemical fluxes, rates of primary production and carbon dynamics.

There are few holistic investigations of ecological processes, connectivity, productivity and resilience in tropical regions (e.g., Amazon; McClain and Naiman 2008), and limited investigative work in the Australian tropics (Hamilton and Gehrke 2005). In terms of the effects of development on river ecosystem processes, there is an important need to reconcile ecological water requirements with proposed developments and commercial water usage in northern Australia (Chan and others 2012; Leigh and others 2012, Stoeckl and others 2013). This includes the importance of hydrological connectivity and its role in mediating the transfer of materials to aquatic organisms. It is also imperative to incorporate ecological understanding and management within a social context (Jackson and others 2011; Naiman 2013; Rieman and others 2015) since the riverine resources are often central to regional communities. 
Whilst water resource development is clearly a contemporary issue that will certainly alter Australian tropical riverscapes, there are other pervasive issues to consider. These include ongoing climate change, sea-level rise and the proliferation of invasive species, especially fire-prone plants (Pusey and others 2011; Catford and others 2013). Riparian zones and floodplains are considered "hotspots" for climate change adaptation (Capon and others 2013) because they may respond either positively or negatively depending on management actions. Riparia and floodplains in the $21^{\text {st }}$ century are likely to play a critical role in determining the vulnerability of natural and human systems to climate change, and in influencing the capacity of systems to adapt. Australia's tropical riparia and floodplains are particularly vulnerable to the impacts of climate change due to their high levels of exposure and sensitivity to climatic stimuli (e.g., flow regimes, importance of seasonal connectivity and fire). It is highly possible that riparia and river-floodplains will maintain resilience to some forms of disturbance such as fire and grazing as a result of their history under substantial levels of climatic and environmental variability. Equally likely, however, is the expectation that they will have low resilience to climate change effects such as rising sea levels.

\section{Acknowledgements}

The authors thank staff at the Centre of Excellence in Natural Resource Management, UWA Albany for their support, as well as advice on figures and tables. We wish to acknowledge Dr Doug Ward, Mr Dominic Valdez (Griffith University) and Prof. Steve Hamilton (Michigan State University) for sharing their ideas and lively discussions in the field and elsewhere. Dr Ward also produced the map for Fig. 1. This research was funded through the Northern Australia Hub of the Australian Government's National Environmental Research Program (NERP). The UWA Institute for Advanced Studies provided support for RJ Naiman, through the 'Professor-at-Large' Programme.

\section{Literature Cited}

Aitkenhead JA, McDowell WH. 2000. Soil C:N ratio as a predictor of annual riverine DOC flux at local and global scales. Global Biogeochemical Cycles 14: 127-138.

Allan JD. 2004. Landscapes and riverscapes: the influence of land use on stream ecosystems. Annual Review of Ecology Evolution and Systematics 35: 257-284.

Arrington DA, Winemiller KO, Layman CA. 2005. Community assembly at the patch scale in a species rich tropical river. Oecologia 144: 157-167.

Balian EV, Segers H, Leveque C, Martens K. 2008. The freshwater animal diversity assessment: an overview of the results. Hydrobiologia 595: 627-637.

Bass AM, O'Grady D, Berkin C, LeBlanc M, Tweed S, Nelson PN, Bird MI. 2013 High diurnal variation in dissolved inorganic $\mathrm{C}, \delta^{13} \mathrm{C}$ values and surface efflux of $\mathrm{CO}_{2}$ in a seasonal tropical floodplain. Environmental Chemistry Letters 11: 399-405. 
Baxter CV, Fausch KD, Saunders WC. 2005. Tangled webs: reciprocal flows of invertebrate prey link streams and riparian zones. Freshwater Biology 50: 201-220.

Bayliss P, Yeomans KM. 1990. Seasonal distribution and abundance of magpie geese, Anseranas semipalmata Latham, in the Northern Territory, and their relationship to habitat, 1983-86. Australian Wildlife Research 17: 15-38.

Bayliss P, van Dam R, Boyden J, Walden D. 2006. Ecological risk assessment of Magela floodplain to differentiate mining and non-mining impacts. Evans KG, Rovis-Hermann J, Webb A, Jones DR, editors. ERISS Research Summary 2004-2005. Supervising Scientist Report 189, Supervising Scientist, Darwin, NT, Australia. p172-185.

Bayliss P, Saunders K, Dutra LX, Melo LF, Hilton J, Prakash M, Woolard F. 2016 Assessing sea level risks to coastal floodplains in the Kakadu Region, Northern Australia, using a tidally driven hydrodynamic model. Marine and Freshwater Research, in press.

Bishop KA, Allen SA, Pollard DA, Cook MG. 1986. Ecological studies on the freshwater fishes of the Alligator Rivers Region, Northern Territory. Volume I. Outline of the study, summary, conclusions and recommendations. Research report 4, Supervising Scientist for the Alligator Rivers Region, AGPS, Canberra, Australia.

Bishop KA, Pidgeon RWJ, Walden DJ. 1995. Studies on fish movement dynamics in a tropical floodplain river: Prerequisites for procedure to monitor the impacts of mining. Australian Journal of Ecology 20: 81-107.

Blanchette ML, Davis AM, Jardine TD, Pearson RG. 2014. Omnivory and opportunism characterise food webs in a large dry-tropics river system. Freshwater Science 33: 142158.

Bond WJ, Keeley JE. 2005. Fire as a global 'herbivore': the ecology and evolution of flammable ecosystems. Trends in Ecology and Evolution 20: 387-94.

Boulton AJ, Boyero L, Covich AP, Dobson M, Lake PS, Pearson RG. 2008. Are tropical streams ecologically different from temperate streams? Dudgeon $D$, editor. Tropical Stream Ecology. Elsevier, London. p257- 284.

Boyero L, Pearson RG, Gessner MO, Dudgeon D, Ramírez A, Yule CM, Callisto M, Pringle CM, Encalada AC, Arunachalam M, Mathooko J, Helson JE, Rincón J, Bruder A, Cornejo A, Flecker AS, Mathuriau C, M'Erimba C, Gonçalves Jr JF, Moretti M, Jinggut T. 2015. Leaflitter breakdown in tropical streams: is variability the norm? Freshwater Science 34: 759-769.

Brito EF, Moulton TP, De Souza ML, Bunn SE. 2006. Stable isotope analysis indicates microalgae as the predominant food source of fauna in a coastal forest stream, southeast Brazil. Austral Ecology 31: 623-633.

Brodie JE, Mitchell AW. 2005. Nutrients in Australian tropical rivers: changes with agricultural development and implications for receiving environments. Marine and Freshwater Research 56: 279-302.

Bunn SE, Arthington A. 2002. Basic principles and ecological consequences of altered flow regimes for aquatic biodiversity. Environmental Management 30: 492-507.

Burford MA, Cook AJ, Fellows CS, Balcombe SR, Bunn SE. 2008. Sources of carbon fuelling production in an arid floodplain river. Marine and Freshwater Research 59: 224-234. 
Burford MA, Revill AT, Palmer DW, Clementson L, Robson BJ, Webster IT. 2011 River regulation alters drivers of primary productivity along a tropical river-estuary system. Marine and Freshwater Research 62: 141-151.

Butler DW, Fairfax RJ. 2003. Buffel grass and fire in a gidgee and brigalow woodland: A case study from central Queensland. Ecological Management and Restoration 4: 120-125.

Capon SJ, Chambers LE, MacNally R, Naiman RJ, Davies P, Marshall N, Pittock J, Reid M, Capon T, Douglas M, Catford J, Baldwin DS, Stewardson M, Roberts J, Parsons M, Williams SE. 2013. Riparian Ecosystems in the $21^{\text {st }}$ Century: Hotspots for Climate Change Adaptation? Ecosystems 16: 359-381.

Catford JA, Naiman RJ, Chambers LE, Roberts J, Douglas M, Davies P. 2013. Predicting novel riparian ecosystems in a changing climate Ecosystems 16: 382-400.

Catford JA, Janson R. 2014. Drowned, buried and carried away: effects of plant traits on the distribution of native and alien species in riparian ecosystems. New Phytologist 204: 1936. doi: 10.1111/nph.12951.

Certini G. 2005. Effects of fire on soil properties of forest soils: a review. Oecologia 143: 110.

Chan T, Hart B, Kennard MJ, Pusey BJ, Shenton W, Douglas M, Valentine E, Patel S. 2012. Bayesian network models for environmental flow decision making in the Daly River, Northern Territory, Australia. River Research and Applications 28: 283-301.

Coley PD, Barone JA. 1996. Herbivory and plant defences in tropical forests. Annual Review of Ecology and Systematics 27: 305-335.

Colloff MJ, Baldwin DS. 2010. Resilience of floodplain ecosystems in a semi-arid environment. Rangeland Journal 32: 305-314.

Cook GD. 1994. The fate of nutrients during fire in a tropical savanna. Australian Journal of Ecology 19: 359-65.

Cook GD. 2003. Fuel dynamics, nutrients and atmospheric chemistry. Andersen AN, Cook G, Williams RJ, editors. Fire in tropical savannas: The Kapalga Experiment. Springer, New York, USA. p47-58.

Cook BD, Kennard MJ, Real K, Pusey BJ, Hughes JM. 2011. Landscape genetic analysis of the tropical freshwater fish Mogurnda mogurnda (Eleotriudae) in a monsoonal river basin: importance of hydrographic factors and population history. Freshwater Biology 56: 812827.

Dambacher JM, Li HW, Rossignol PA. 2002. Relevance of community structure in assessing indeterminacy of ecological predictions. Ecology 83: 1372-1385.

Davies PM. 2010. Climate change implications for river restoration in global biodiversity hotspots. Restoration Ecology 18: 261-268.

Davies PM, Bunn SE, Hamilton SK. 2008. Primary production in tropical streams and rivers. Dudgeon D, editor. Tropical Stream Ecology. Elsevier, London. p23-42.

Davies PM, Naiman RJ, Warfe DM, Pettit NE, Arthington AH, Bunn SE. 2014. Flow-ecology relationships: closing the loop on effective environmental flows. Marine and Freshwater Research 65: 133-141.

Davis AM, Pusey BJ, Thorburn DC, Dowe JL, Morgan DL, Burrows D. 2010. Riparian contributions to the diet of terapontid grunters (Pisces: Terapontidae) in wet-dry tropical rivers. Journal of Fish Biology 76: 862-879. 
Davis AM, Pearson RG, Brodie JE, Butler B. 2016. Review and conceptual models of agricultural impacts and water quality in tropical and sub-tropical waterways of the Great Barrier Reef catchment area. Marine and Freshwater Research online (doi.org/10.1071/MF15301).

Douglas MM, O'Connor RA. 2004. Weed invasion changes fuel characteristics: Para grass (Urochloa mutica (Forssk.) T.Q. Nguyen) on a tropical floodplain. Ecological Management and Restoration 5: 143-145.

Douglas MM, Bunn SE, Davies PM. 2005. River and wetland food webs in Australia's wet-dry tropics: general principles and implications for management. Marine and Freshwater Research 56: 329-342.

Douglas MM, Setterfield SA, McGuinness K, Lake PS. 2015. The impact of fire on riparian vegetation in Australia's tropical savanna. Freshwater Science 34: 1351-1365.

Douglas MM, Pettit NE, Setterfield SA. 2016. Fire in Australia's riparian landscapes. Capon S, Reid M, James C, editors. Australian Riparian Landscapes. CSIRO Publishing, Clayton, Melbourne, Australia. p297-306.

Doupé RG, Pettit NE. 2002. Ecological perspectives on regulation and water allocation for the Ord River, Western Australia. River Research and Applications 18: 307-320.

Dudgeon D. 2000. The ecology of tropical Asian rivers and streams in relation to biodiversity conservation. Annual Review of Ecology and Systematics 31: 239-263.

Dudgeon D. 2006. The impacts of human disturbance on stream benthic invertebrates and their drift in North Sulawesi, Indonesia. Freshwater Biology 51: 1710-1729.

Edwards A, Kennett R, Price O, Russell-Smith J, Spiers G, Woinarski J. 2003. Monitoring the impacts of fire regimes on vegetation in northern Australia: an example from Kakadu National Park. International Journal of Wildland Fire 12: 427-440.

Faggotter SJ, Webster IT, Burford MA. 2013. Factors controlling primary productivity in a wet-dry tropical river. Marine and Freshwater Research 64: 585-598.

Fausch KD, Torgersen CE, Baxter CV, Li HW. 2002. Landscapes to riverscapes: bridging the gap between research and conservation of stream fishes. BioScience 52: 483-498.

Fellman JB, Dogramaci S, Skrzypek G, Dodson W. Grierson PF. 2011. Hydrologic control of dissolved organic matter biogeochemistry in pools of a subtropical dryland river. Water Resources Research 47: W06501.

Fellman JB, Pettit NE, Kalic J, Grierson PF. 2013. Influence of stream-floodplain biogeochemical linkages on aquatic foodweb structure along a gradient of stream size in a tropical catchment. Freshwater Science 32: 217-229.

Fellman JB, Spencer RGM, Raymond PA, Pettit NE, Skrzypek G, Grierson PF. 2014. Dissolved organic carbon biolability decreases along with its modernisation in fluvial networks in an ancient landscape. Ecology 95: 2622-2632.

Ferdinands K, Beggs K, Whitehead P. 2005. Biodiversity and invasive grass species: multipleuse or monoculture? Wildlife Research 32: 447-457.

Finer M, Jenkins CN. 2013. Proliferation of hydroelectric dams in the Andean Amazon and implications for Andes-Amazon connectivity. PLoS One 7: e35126.

Finlayson CM. 1991. Production and major nutrient composition of three grass species on the Magela floodplain, Northern Territory, Australia. Aquatic Botany: 41: 263-280. 
Finlayson CM, Cowie ID, Bailey BJ. 1993. Biomass and litter dynamics in a Melaleuca forest on a seasonally inundated floodplain in tropical, northern Australia. Wetland Ecology and Management 2: 177-188.

Finlayson CM. 2005. Plant ecology of Australia's tropical floodplain wetlands: A review. Annals of Botany 96: 541-555.

Fisher SG, Sponseller RA, Heffernan JB. 2004. Horizons in stream biogeochemistry: Flow paths to progress. Ecology 85: 2369-2379.

Fausch KD, Torgersen CE, Baxter CV, Li HW. 2002. Landscapes to riverscapes: bridging the gap between research and conservation of stream fishes. BioScience 52: 483-498.

Ganf GG, Rea N. 2007. Potential for algal blooms in tropical rivers of the Northern Territory, Australia. Marine and Freshwater Research 58: 315-326.

Garcia EA, Dostine P, Humphrey C, Douglas M, Pusey B, Cook B. 2011. Aquatic Macroinvertebrates. Pusey BJ editor. Aquatic Biodiversity in Northern Australia: Patterns, Threats and Future. Charles Darwin University Press, Darwin. p51-70.

Garcia EA, Townsend SA, Douglas MM. 2015a. Context dependency of top-down and bottom-up effects in a Northern Australian tropical River. Freshwater Science 34: 679690.

Garcia EA, Pettit NE, Warfe DM, Davies PM, Kyne PM, Novak P. Douglas MM. 2015b. Temporal variation in benthic production in streams of the Australian wet-dry tropics. Hydrobiologia 760: 43-55.

Garzon-Garcia A, Bunn SE, Olley JM, Oudyn F. 2015. Controls on carbon and nitrogen export in an eroding catchment of south-eastern Queensland, Australia. Hydrological Processes 29: 739-751.

Gill AM, Ryan PG, Moore PHR, Gibson M. 2000. Fire regimes of world heritage Kakadu National Park. Austral Ecology 25: 616-625.

Goldberg ED. 1985. Black Carbon in the Environment. John Wiley, New York, USA.

Guenet B, Danger M, Abbadie L, Lacroix G. 2010. Priming effect: bridging the gap between terrestrial and aquatic ecology. Ecology 91: 2850-2861.

Gunderson LH, Holling CS, editors. 2002. Panarchy: understanding transformations in human and natural systems. Island Press, Washington DC, USA.

Gunderson LH, Holling CS, Pritchard L, Peterson GD. 2002. Resilience of large-scale resource systems. Gunderson LH, Pritchard L. editors. Resilience and the behaviour of largescale systems. Island Press, Washington DC, USA. p3-20.

Hamilton SK. 2010. Biogeochemical implications of climate change for tropical rivers and floodplains. Hydrobiologia 657: 19-35.

Hamilton SK, Gehrke PC. 2005. Australia's tropical river systems: current scientific understanding and critical knowledge gaps for sustainable management. Marine and Freshwater Research 56: 243-252.

Hamilton SK, Lewis WMJ, Sippel SJ. 1992. Energy sources for aquatic animals in the Orinoco River floodplain: evidence from stable isotopes. Oecologia 89: 324-330.

Hanson JO, Salisbury SW, Campbell HA, Dwyer RG, Jardine TD, Franklin CE. 2015, Feeding across the food web: The interaction between diet, movement and body size in estuarine crocodiles (Crocodylus porosus). Austral Ecology 40: 275-286. 
Hart BT, Ottaway EM, Noller BN. 1987. Magela Creek system, northern Australia, I. 1982-83 wet season water quality. Australian Journal of Marine and Freshwater Research 38: 261-288.

Hoeinghaus DJ, Winemiller KO, Agostinho AA. 2007. Landscape-scale hydrologic characteristics differentiate patterns of carbon flow in large-river food webs. Ecosystems 10: 1019-1033.

Humphries P, Keckeis H, Finlayson B. 2014. The River Wave Concept: Integrating River Ecosystem Models. BioScience 64: 870-882.

Hunt RJ, Jardine TD, Hamilton SK, Bunn SE. 2012. Temporal and spatial variation in ecosystem metabolism and food web carbon transfer in a wet-dry tropical river. Freshwater Biology 57: 435-450.

Jackson S, Pusey B, Douglas M. 2011. Indigenous community-based management of tropical freshwater systems. Pusey BJ editor. Aquatic biodiversity in northern Australia: patterns, threats and future. Charles Darwin University, Darwin, Australia. p203-220.

Jackson S, Finn M, Featherston P. 2012. Aquatic resource use by Indigenous Australians in two tropical river catchments: the Fitzroy River and Daly River. Human Ecology 40: 893908.

Jardine TD. 2016. A top predator forages low on species-rich tropical food chains. Freshwater Science. In press. DOI: 10.1086/685858

Jardine TD, Warfe DM, Pettit NE, Hamilton SK, Burford M, Garcia E, Bunn SE, Douglas MM. 2011. Natural processes supporting biodiversity in tropical rivers of Northern Australia. Pusey BJ, editor. Aquatic biodiversity in northern Australia: patterns, threats and future. Charles Darwin University Press, Darwin, Australia. p5-22.

Jardine TD, Pettit NE, Warfe DM, Pusey BJ, Ward DP, Douglas MM, Davies PM, Bunn SE. 2012a. Consumer-resource coupling in wet-dry tropical rivers. Journal of Animal Ecology 81: 310-322.

Jardine TD, Pusey BJ, Hamilton SK, Pettit NE, Davies PM, Douglas MM, Sinnamon V, Halliday IA, Bunn SE 2012b. Fish mediate high food web connectivity in the lower reaches of a tropical floodplain river. Oecologia 168: 829-838.

Jardine TD, Hunt RJ, Faggotter SJ, Valdez D, Burford MA, Bunn SE. 2013. Carbon from periphyton supports fish biomass in waterholes of a wet-dry tropical river. River Research and Applications 29: 560-573.

Jardine TD, Bond NR, Burford MA, Ward DP, Bayliss P, Davies PM, Douglas MM, Hamilton SK, Kennard MJ, Melack JM, Naiman RJ, Olley JM, Pettit NE, Pusey BJ, Warfe DM, Bunn SE. 2015. Does flood rhythm drive ecosystem responses in tropical riverscapes? Ecology 96: 684-692.

Jenkins RWG, Forbes MA. 1985. Seasonal variation in abundance and distribution of Crocodylus porosus in the tidal East Alligator River, Northern Australia. Grigg G, Shine R, Ehmann H, editors. Biology of Australian Frogs and Reptiles.. Surrey Beatty and Sons, Sydney, Australia. p63-69.

Jepsen DB, Winemiller KO. 2002. Structure of tropical river food webs revealed by stable isotope ratios. Oikos 96: 46-55.

Junk WJ, Bayley PB, Sparks RE. 1989. The flood pulse concept in river-floodplain system. Canadian Journal of Fisheries and Aquatic Sciences (Special Pub) 106: 110-127. 
Junk WJ, Wantzen KM. 2004. The flood pulse concept: new aspects, approaches and applications - an update. Welcomme RL, Petr T, editors. 2nd International Symposium on the Management of Large Rivers for Fisheries. FAO and Mekong River Commission, Bangkok, Thailand. p117-140.

Kennard MJ, Pusey BJ, Olden JD, Mackay S, Stein J, Marsh N. 2010. Classification of natural flow regimes in Australia to support environmental flow management. Freshwater Biology 55: 171-193.

King AJ, Townsend SA, Douglas MM, Kennard MJ. 2015. Implications of water extraction on the low-flow hydrology and ecology of tropical savannah rivers: an appraisal for northern Australia. Freshwater Science 34: 741-758.

Kufel L, Kufel I. 2002. Chara beds acting as nutrient sinks in shallow lakes-a review. Aquatic Botany 72: 249-260.

Lambert T, Darchambeau F, Boullion S, Alhou B, Mbega JD, Teodoru CR, Nyoni FC, Massicotte P, Borges AV. 2015. Landscape Control on the Spatial and Temporal Variability of Chromophoric Dissolved Organic Matter and Dissolved Organic Carbon in Large African Rivers. Ecosystems 18: 1224-1239.

Lake PS, Bond N. Reich P. 2006. Floods down rivers: from damaging to replenishing forces. Advances in Ecological Research 39: 41-62.

Lake PS, Bond N, Reich P. 2007. Linking ecological theory with stream restoration. Freshwater Biology 52: 597-615.

Lau DCP, Leung KMY, Dudgeon D. 2009. Are autochthonous foods more important than allochthonous resources to benthic consumers in tropical headwater streams? Journal of the North American Benthological Society 28: 426-439.

Layman CA, Winemiller KO, Arrington DA, Jepsen DB. 2005. Body size and trophic position in a diverse tropical food web. Ecology 86: 2530-2535.

Leigh C, Sheldon F. 2009. Hydrological connectivity drives patterns of macroinvertebrate diversity in floodplain rivers of the Australian wet/dry tropics. Freshwater Biology 54: 549-571.

Leigh CL, Burford MA, Sheldon F, Bunn SE. 2010. Dynamic stability in dry season food webs within tropical floodplain rivers. Marine and Freshwater Research 61: 357-368.

Leigh C, Stewart-Koster B, Sheldon F, Burford MA. 2012. Understanding multiple ecological responses to anthropogenic disturbance: rivers and potential flow regime change. Ecological Applications 22: 250-263.

Lewis WM. 2008. Physical and chemical features of tropical flowing waters. Dudgeon D, editor. Tropical Freshwater Ecology. Academic Press, Amsterdam, Netherlands. p2-23.

Lewis WM, Hamilton SK, Lasi MA, Rodriguez M, Saunders JF. 2000. Ecological determinism on the Orinoco Floodplain. Bioscience 50: 681-692.

Lewis WM, Hamilton SK, Rodriguea MA, Saunders JFI, Lasi MA. 2001. Foodweb analysis of the Orinoco floodplain based on production estimates and stable isotope data. Journal of the North American Benthological Society 20: 241-254.

Loneragan NR, Bunn SE. 1999. River flows and estuarine ecosystems: implications for coastal fisheries from a review and a case study of the Logan River, southeast Queensland.

Australian Journal of Ecology 24: 431-440. 
Lytle DA, Poff NL. 2004. Adaptation to natural flow regimes. Trends in Ecology and Evolution 19: 94-100.

Madsen T, Shine R. 2000. Rain, fish and snakes: climatically driven population dynamics of Arafura filesnakes in tropical Australia. Oecologia 124: 208-215.

Marcarelli AM, Baxter CV, Mineau MM, Hall RO Jr. 2011. Quantity and quality: unifying food web and ecosystem perspectives on the role of resource subsidies in freshwaters. Ecology 92: 1215-1225.

McCann KS, Rasmussen JB, Umbanhowar J. 2005. The dynamics of spatially coupled foodwebs. Ecology Letters 8: 513-523.

McCann KS, Rooney N. 2009. The more food webs change, the more they stay the same. Philosophical Transactions of the Royal Society B 364: 1789-1801.

McClain ME, Richey JE, Brandes JA, Pimentel TP. 1997. Dissolved organic matter and terrestrial-lotic linkages in the central Amazon basin of Brazil. Global Biogeochemical Cycles 11: 295-311.

McClain ME, Boyer EW, Dent CL, Gergel SE, Grimm NB, Groffman PM, Hart SC, Harvey JW, Johnston CA, Mayorga E, McDowell WH, Pinay G. 2003. Biogeochemical hot spots and hot moments at the interface of terrestrial and aquatic ecosystems. Ecosystems 6: 30112.

McClain ME, Naiman RJ. 2008. Andean influences on the biogeochemistry and ecology of the Amazon River. BioScience 58: 325-338.

McClain ME, Subalusky AL, Anderson EP, Dessu SB, Melesse AM, Ndomba PM, Mtamba JOD, Tamatamah RA, Mligo C. 2014. Comparing flow regime, channel hydraulics and biological communities to infer flow-ecology relationships in the Mara River of Kenya and Tanzania. Hydrological Sciences Journal 59: 801-819.

McGregor S, Lawson V, Christopherson P, Kennett R, Boyden J, Bayliss P, Liedloff A, McKaige $B$, Anderson A. 2010. Indigenous wetland burning: Conserving natural and cultural resources in Australia's World heritage-listed Kakadu National Park. Human Ecology 38: 721-729.

McIntyre RES, Adams MA, Ford DJ, Grierson PF. 2009. Rewetting and litter addition influence mineralization and microbial communities in soils from a semi-arid intermittent stream. Soil Biology and Biochemistry 41: 92-101.

Merriam JL, McDowell WH, Tank JL, Wollheim WM, Crenshaw CL and Johnson SL . 2002. Characterizing nitrogen dynamics, retention and transport in a tropical rainforest stream using an in situ ${ }^{15} \mathrm{~N}$ addition. Freshwater Biology 47: 143-160.

Morton SR, Brennan KG, Armstrong MD. 1990. Distribution and abundance of magpie geese, Anseranas semipalmata, in the Alligator Rivers region, Northern Territory. Australian Journal of Ecology 15: 307-320

Mulholland PJ, Marzolf ER, Hendricks SP, Wilkerson RV, Baybayan AK. 1995. Longitudinal patterns of nutrient cycling and periphyton characteristics in streams: A test of upstream-downstream linkage. Journal of the North American Benthological Society 14: 357-370.

Naiman RJ, Melillo JM, Lock MA, Ford TE, Reice SR. 1987. Longitudinal patterns of ecosystem processes and community structure in a subarctic river continuum. Ecology 68: 1139-1156. 
Naiman RJ, Décamps H. 1997. The ecology of interfaces: riparian zones. Annual Review of Ecology Evolution and Systematics 28: 621-658.

Naiman RJ. 2013. Socio-ecological complexity and the restoration of river ecosystems. Inland Waters 3: 391-410.

Naiman RJ, Alldredge JR, Beauchamp D, Bisson P A, Congleton J, Henny CJ, Huntly N, Lamberson R, Levings C, Merrill E, Pearcy W, Rieman B, Ruggerone G, Scarnecchia D, Smouse P, Wood CC. 2012. Developing a broader scientific foundation for river restoration: Columbia River food webs. Proceedings of the National Academy of Sciences USA 109: 21201-21207.

Naiman RJ, Latterell JJ, Pettit NE, Olden JD. 2008. Flow variability and the biophysical vitality of river systems. Comptes Rendus Geoscience 340: 629-643.

Novak PA, Douglas MM, Garcia EA, Bayliss P, Pusey BJ. 2015. A life-history account of Macrobrachium spinipes (Schenkel, 1902) (Cherabin) in a large tropical Australian River. Freshwater Sciences 34: 620-633.

Opperman JJ, Luster R, McKenney BA, Roberts M, Meadows AW. 2010. Ecologically functional floodplains: connectivity, flow regime and scale. Journal of the American Water Resources Association 46: 211-226.

Parsons M, McLoughlin CA, Rountree MW, Rogers KH. 2006. The biotic and abiotic legacy of a large infrequent flood disturbance in the Sabie River, South Africa. River Research and Applications 22: 187-201.

Parsons M, Thoms M, Capon T, Capon S, Reid M. 2009. Resilience and thresholds in river ecosystems, Waterlines report. National Water Commission, Canberra, Australia.

Pearson RG, Connolly N. 2000. Nutrient enhancement, food quality and community dynamics in a tropical rainforest stream. Freshwater Biology 43: 31-42.

Pearson RG, Connolly N, Boyero L. 2015. Ecology of streams in a biogeographic isolate - the Queensland Wet Tropics, Australia. Freshwater Science 34: 797-819.

Perna C, Pearson RG. 2008. Temporal dynamics of fish assemblages in small seasonal streams in the Queensland tropics. Australian Journal of Zoology 56: 65-73.

Pettit NE, Froend RH. 2001 Variability in flood disturbance and the impact on riparian tree recruitment in two contrasting river systems. Wetland Ecology and Management 9: 1325.

Pettit NE, Froend RH, Davies PM. 2001. Identifying the natural flow regime and the relationship with riparian vegetation for two contrasting Western Australian rivers. Regulated Rivers: Research and Management 17: 201-215.

Pettit NE, Naiman RJ. 2005. Flood deposited wood debris and its contribution to heterogeneity and regeneration in a semi-arid riparian landscape. Oecologia 145: 434444.

Pettit NE, Naiman RJ. 2007. Fire in the riparian zone: Characteristics and ecological consequences. Ecosystems 10: 673-687.

Pettit NE, Bayliss P, Davies PM, Hamilton SK, Warfe DM, Bunn SE, Douglas MM. 2011. Seasonal contrasts in carbon resources and ecological processes on a tropical floodplain. Freshwater Biology 56: 1047-1064. 
Pettit NE, Jardine TD, Hamilton SK, Sinnamon V, Valdez D, Davies PM, Douglas MM, Bunn SE. 2012a. Seasonal changes in water quality and macrophytes and the impact of cattle on tropical floodplain waterholes. Marine and Freshwater Research 63: 788-800.

Pettit NE, Davies T, Fellman JB, Grierson PF, Warfe DM, Davies PM. 2012b. Leaf chemistry, decomposition and assimilation by macroinvertebrates in two tropical streams. Hydrobiologia 680: 63-77.

Pettit NE, Warfe DM, Kennard MJ, Pusey BJ, Davies PM, Douglas MM. 2013. Dynamics of instream wood and its importance as fish habitat in a large tropical floodplain river. River Research and Applications 29: 864-875.

Pettit NE, Ward DP, Adame MF, Valdez D, Bunn SE. 2016. Influence of aquatic plant architecture on epiphyte biomass on a tropical river floodplain. Aquatic Botany 129: 3543.

Petty AM, Werner PA, Lehmann CER, Riley JE, Banfai DS, Elliot LP. 2007. Savanna responses to feral buffalo in Kakadu National Park, Australia. Ecological Monographs 77: 441-463.

Petty AM, Douglas MM. 2010. Scale relationships and linkages between woody vegetation communities along a large tropical floodplain river, north Australia. Journal of Tropical Ecology 26: 79-92.

Poff NL, Allan JD. 1995. Functional organisation of stream fish assemblages in relation to hydrological variability. Ecology 76: 606-627.

Poff NL, Allan JD, Bain MB, Karr JR, Prestegaard KL, Richter BD, Sparks RE, Stromberg, JC. 1997. The natural flow regime: A paradigm for river conservation and restoration. Bioscience 47: 769-784.

Power ME, Parker MS, Dietrich WE. 2008. Seasonal reassembly of a river food web: Floods, droughts, and impacts of fish. Ecological Monographs 78: 263-282.

Pusey BJ, Arthington AH. 2003. Importance of the riparian zone to the conservation and management of freshwater fish: a review. Marine and Freshwater Research 54: 1-16.

Pusey BJ, Kennard MJ, Burrows D, Perna C, Kyne P, Cook B, Hughes J. 2011. Freshwater Fish. Pusey BJ, editor. Aquatic Biodiversity in Northern Australia: Patterns, threats and Future. Charles Darwin University Press, Darwin, Australia.

Pusey BJ, editor. 2011. Aquatic Biodiversity in Northern Australia: Patterns, threats and Future. Charles Darwin University Press, Darwin, Australia.

Rayner TS, Pusey BJ, Pearson RG. 2009. Spatio-temporal dynamics of fish feeding in the lower Mulgrave River, north-eastern Queensland: the influence of seasonal flooding, instream productivity and invertebrate abundance. Marine and Freshwater Research 60: 97-111.

Rayner TS, Pusey BJ, Pearson RG, Godfrey PC. 2010. Food web dynamics in an Australian Wet Tropics river. Marine and Freshwater Research 61: 909-917.

Richards AE, Cook GD, Lynch BT. 2011. Optimal Fire Regimes for Soil Carbon Storage in Tropical Savannas of Northern Australia. Ecosystems 14: 503-518

Richey JE, Hedges JI, Devlo AH, Quay PD, Vicoria R, Martinelli L, Forsberg BR. 1990. Biogeochemistry of carbon in the Amazon River. Limnology and Oceanography 35: 352371. 
Rieman BE, Smith CL, Naiman RJ, Ruggerone G, Wood CC, Huntly N, Merrill EN, Alldredge JR, Bisson PA, Congleton J, Fausch K, Levings C, Pearcy W, Scarnecchia D, Smouse P. 2015. A comprehensive approach for habitat restoration in the Columbia Basin. Fisheries 40: 124-135.

Rodriguez MA, Lewis WM. 1997. Structure of fish assemblages along environmental gradients in floodplain lakes of the Orinoco River. Ecological Monographs 67: 109-128.

Rossiter NA, Setterfield SA, Douglas MM, Hutley LB. 2003. Testing the grass-fire cycle: alien grass invasion in the tropical savannas of northern Australia. Diversity and Distributions 9: 169-176.

Russell-Smith JM, Ryan PG, Durieu R. 1997. A LANDSAT MSS-derived fire history of Kakadu National Park, monsoonal northern Australia, 1980-94: seasonal extent, frequency and patchiness. Journal of Applied Ecology 34: 748-766.

Sabo JL, Power ME. 2002. River-watershed exchange: effects of riverine subsidies on riparian lizards and their terrestrial prey. Ecology 83: 1860-1869.

Saunders TJ, McClain ME, Llerena CA. 2006. The biogeochemistry of dissolved nitrogen, phosphorus, and organic carbon along terrestrial aquatic flow paths of a montane headwater catchment in the Peruvian Amazon. Hydrological Processes 20: 2549-2562.

Scheffer M, Szabo S, Gragnani A, van Nes EH, Rinaldi S, Kautsky N, Norberg J, Roijackers RM $M$, Franken RJM. 2003. Floating plant dominance as a stable state. Proceedings of the National Academy of Sciences USA 100: 4040-4045.

Schindler DE, Carpenter SR, Cole JJ, Kitchell JF, Pace ML. 1997. Influence of food web structure on carbon exchange between lakes and the atmosphere. Science 277: 248251.

Schmidt MW, Noack AG. 2000. Black carbon in soils and sediments: Analysis, distribution, implications and current challenges. Global Biogeochemistry Cycles 14: 777-793.

Schult J, Townsend S, Douglas M, Webster I, Skinner S, Casanova M. 2007. Recommendations for Nutrients Resource Condition Targets for the Daly River. Charles Darwin University, Darwin, Australia.

Siebers AR, Pettit NE, Skrzypek G, Fellman JB, Dogramaci S, Grierson PF. 2016. Alluvial ground water influences dissolved organic matter biogeochemistry of pools within intermittent dryland streams. Freshwater Biology 61: 1228-1241.

Skeat AJ, East JT, Corbett LK. 1996. Impact of feral water buffalo. Finlayson M, von Oertzen I editors. Landscape and vegetation ecology of the Kakadu Region, Northern Australia. Kluwer Academic Publishers, Netherlands. p155-177.

Stein JL, Stein JA, Nix HA. 2002. Spatial analysis of anthropogenic river disturbance at regional and continental scales: identifying the wild rivers of Australia. Landscape and Urban Planning 60: 1-25.

Stewart-Koster B, Olden JD, Kennard MJ, Pusey BJ, Boone EL, Douglas M, Jackson S. 2011. Fish response to the temporal hierarchy of the natural flow regime in the Daly River, northern Australia. Journal of Fish Biology 79: 1525-1544.

Stoeckl N, Jackson S, Pantus F, Finn M, Kennard MJ, Pusey BJ. 2013. An integrated assessment of financial, hydrological, ecological and social impacts of 'development' on Indigenous and non-Indigenous people in northern Australia. Biological Conservation 159: 214-221. 
Stuart SN, Chanson JS, Cox NA, Young BE, Rodrigues AS, Fischman DL, Waller RW. 2004. Status and trends in amphibian declines and extinctions worldwide. Science 306: 17831786.

Tabacchi E, Lambs L, Guilloy H, Planty-Tabacchi AM, Muller E, D'ecamps H. 2000. Impacts of riparian vegetation on hydrological processes. Hydrological Processes 14: 2959-2976.

Takimoto G, Post D.M. 2013. Environmental determinants of food-chain length: a metaanalysis. Ecological Restoration 28: 675-681.

Thompson RM, Dunne J, Woodward G. 2012. Freshwater food webs: towards a more fundamental understanding of biodiversity and community dynamics. Freshwater Biology 57: 1329-1341.

Thorp JH, Thoms MC, Delong MC. 2006. The riverine ecosystem synthesis: biocomplexity in river networks across space and time. River Research and Applications 22: 123-147.

Tockner K, Malard F, Ward JV. 2000. An extension of the flood pulse concept. Hydrological Processes 14: 2861-2883.

Townsend SA, Boland KT, Wrigley JT. 1992. Factors contributing to a fish kill in the Australian wet-/dry tropics. Water Resources 26: 1039-1044.

Townsend SA, Padovan AV. 2005. The accrual and loss of benthic algae (Spirogyra) in the Daly River, an oligotrophic river in tropical Australia. Marine and Freshwater Research 56: 317-327.

Townsend SA, Schult JH, Douglas MM, Skinner S. 2008. Does the Redfield ratio infer nutrient limitation in the macroalga Spirogyra fluviatilis. Freshwater Biology 53: 509-520.

Townsend SA, Webster IT, Schult JH. 2011. Metabolism in a groundwater-fed river system in the Australian wet/dry tropics: tight coupling of photosynthesis and respiration. Journal of the North American Benthological Society 30: 603-620.

Townsend SA, Przybyska M, Miloshis M. 2012. Phytoplankton composition and constraints to biomass in the middle reaches of an Australian tropical river during base flow. Marine and Freshwater Research 63: 48-59.

Townsend SA, Douglas MM. 2014. Benthic algal resilience to frequent wet-season storm flows in low-order streams in the Australian tropical savannah. Freshwater Science 33: 1030-1042.

Turton SM. 2012 Securing landscape resilience to tropical cyclones in Australia's wet tropics under a changing climate: lessons from cyclone Larry (and Yasi). Geographical Research 50: $15-30$.

Vannote RL, Minshall GW, Cummins KW, Sedelland JR, Cushing CE. 1980. The river continuum concept. Canadian Journal of Fisheries and Aquatic Sciences 37: 130-137.

Vanni MJ. 2002 Nutrient cycling by animals in freshwater ecosystems. Annual Review of Ecology Evolution and Systematics 33: 341-370.

van Wilgen BW, Trollope WSW, Biggs HC., Potgieter ALF, Brockett BH. 2003. Fire as a driver of ecosystem variability. du Toit JT, Rogers KH, Biggs HC editors. The Kruger experience: ecology and management of savanna heterogeneity. Island Press, Washington USA. p149-70.

Vörösmarty CJ, McIntyre PB, Gessner MO, Dudgeon D, Prusevich A, Green P, Glidden S, Bunn SE, Sullivan CA, Reidy Liermann C, Davies PM. 2010. Global threats to human water security and river biodiversity. Nature 467: 555-561. 
Walker B, Salt D. 2006. Resilience thinking: Sustaining ecosystems and people in a changing world. Island Press, Washington DC, USA.

Wantzen KM, Rothhaupt KO, Mortl M, Cantonati M, Toth L, Fischer. 2008. Ecological effects of water-level fluctuations in lakes: an urgent issue. Hydrobiologia 613: 1-4.

Ward JV, Tockner K, Schieme F. 1999. Biodiversity of floodplain river ecosystems: ecotones and connectivity. Regulated Rivers: Research and Management 15: 125-139.

Ward JV, Tockner K. 2001. Biodiversity: towards a unifying theme for river ecology. Freshwater Biology 46: 807-819.

Ward DP, Pusey BJ, Brooks A, Olley J, Shellburg J, Spencer J, Tews, K. 2011. River landscapes and aquatic systems diversity. Pusey BJ, editor. Aquatic biodiversity of the Wet-Dry Topics of Northern Australia: patterns, threats and future. Charles Darwin University Press, Darwin, Australia. p5-22

Ward DP, Hamilton SK, Jardine TD, Pettit NE, Tews EK, Olley JM, Bunn SE. 2013. Assessing the seasonal dynamics of inundation, turbidity, and aquatic vegetation in the Australian wet-dry tropics using optical remote sensing. Ecohydrology 6: 312-323.

Ward DP, Petty A, Setterfield SA, Douglas MM, Ferdinands K, Phinn S. 2014. Floodplain inundation and vegetation dynamics in the Alligators Rivers region (Kakadu) of northern Australia assessed using optical and radar remote sensing. Remote Sensing of Environment 147: 43-55.

Warfe DM, Pettit NE, Davies PM, Pusey BJ, Hamilton SK, Kennard MJ, Townsend SA, Bayliss P, Ward DP, Douglas MM, Burford MA, Finn M, Bunn SE, Halliday IA. 2011. The 'wet-dry' in the wet-dry tropics drive river ecosystem structure and processes in northern Australia. Freshwater Biology 56: 2169-2195.

Warfe DM, Pettit NE, Magierowski RH, Pusey BJ, Davies PM, Douglas MM, Bunn SE. 2013a. Hydrological connectivity structures concordant plant and animal assemblages according to niche rather than dispersal processes. Freshwater Biology 58: 292-305.

Warfe DM, Jardine TD, Pettit NE, Hamilton SK, Pusey BJ, Bunn SE, Davies PM, Douglas MM. 2013b. Classical determinants of food chain length have no effect in seasonally connected river-floodplain ecosystems. PlosOne 8(6), e66240, doi:10.1371/journal.pone.0066240.

Wasson RJ, Furlonger L, Parry D, Pietsch T, Valentine E, Williams D. 2010. Sediment sources and channel dynamics, Daly River, Northern Australia. Geomorphology 114: 161-174.

Webb GJW, Messel H, Magnusson W. 1977. The nesting of Crocodylus porosus in Arnhem Land, northern Australia. Copeia 1977: 238-249.

Whitehead PJ, Saalfeld K. 2000. Nesting phenology of magpie geese (Anseranas semipalmata) in monsoonal northern Australia: responses to antecedent rainfall. Journal of Zoology 251: 495-508.

Winemiller KO. 1990. Spatial and temporal variation in tropical fish trophic networks. Ecological Monographs 60: 331-367.

Winemiller KO. 1996. Dynamic diversity in fish assemblages of tropical rivers. Cody ML, Smallwood JA, editors. Long-Term Studies of Vertebrate Communities. Academic Press, Sand Diego, USA. p99-134.

Winemiller KO, Jepsen DB. 1998. Effects of seasonality and fish movement on tropical river food webs. Journal of Fish Biology 53: 267-296. 
Winemiller KO. 2004. Floodplain river food webs: generalization and implications for fisheries management. Welcomme RL, Petr T, editors. Proceedings of the Second International Symposium on the Management of Large Rivers for Fisheries, Volume II. FAO, RAP Publication 2004/16, Bangkok, Thailand. p285-309.

Winemiller KO, Montana CG, Roelke DL, Cotner JB, Montoya JV, Sanchez L, Castillo MM, Layman CA. 2014. Pulsing hydrology determines top-down control of basal resources in a tropical river-floodplain ecosystem. Ecological Monographs 84: 621-635.

Woinarski J, Mackey B, Nix H, Traille B. 2007. The Nature of Northern Australia: Natural Values, Ecological Processes and Future Prospects. ANU E Press, Canberra, Australia.

Zarfl C, Lumsdon AE, Berlekamp J, Tydecks L, Tockner K. 2015. A global boom in hydropower dam construction. Aquatic Sciences 77: 161-170.

Zeug SC, Winemiller KO. 2008. Evidence supporting the importance of terrestrial carbon in a large-river food web. Ecology 89: 1733-1743. 


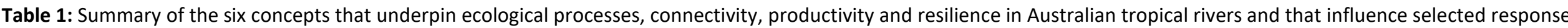
variables. Estimates of spatio-temporal variability, knowledge reliability and key references to studies from Australian and other tropical rivers are provided.

\begin{tabular}{|c|c|c|c|c|c|}
\hline Concept & Response variable & $\begin{array}{l}\text { Spatio- } \\
\text { temporal } \\
\text { variability }\end{array}$ & $\begin{array}{l}\text { Knowledge } \\
\text { reliability }^{1}\end{array}$ & Evidence - Tropical Australia & Evidence - Other Tropical rivers \\
\hline \multirow[t]{2}{*}{$\begin{array}{l}\text { 1. Flow pattern } \\
\text { variability }\end{array}$} & Primary productivity & Mod- High & High & $\begin{array}{l}\text { Finlayson and others 1993; Davies and others 2008; Pettit } \\
\text { and others 2011; Warfe and others } 2011 .\end{array}$ & Winemiller 1990; Hamilton 2010. \\
\hline & $\begin{array}{l}\text { Biodiversity and } \\
\text { habitat connectivity }\end{array}$ & Mod-High & Moderate & $\begin{array}{l}\text { Morton and others 1990; Bishop and others 1995; } \\
\text { Leigh and Sheldon 2009; Pusey and others 2011; Warfe and } \\
\text { others 2013a; Jardine and others } 2015\end{array}$ & $\begin{array}{l}\text { Dudgeon 2000; Dudgeon 2006; Stuart and others 2004; } \\
\text { Balian and others 2008; Vörösmarty and others } 2010 .\end{array}$ \\
\hline \multirow[t]{3}{*}{$\begin{array}{l}2 . \\
\text { Biogeochemistry }\end{array}$} & $\begin{array}{l}\text { Nutrient supply to } \\
\text { primary producers }\end{array}$ & Unknown & Low & $\begin{array}{l}\text { Finlayson 2005; Pettit and others 2011; Faggotter and } \\
\text { others 2013; Jardine and others 2013; Fellman and others } \\
\text { 2014; Townsend and others } 2012 .\end{array}$ & $\begin{array}{l}\text { Lewis and others 2000; Hamilton 2010; Saunders and others } \\
\text { 2006; Merriam and others 2002; McClain and others } 2003 .\end{array}$ \\
\hline & DOC exchange & Unknown & Low & $\begin{array}{l}\text { Townsend and others 2011; Fellman and others 2013; } \\
\text { Fellman and others } 2014 \text {. }\end{array}$ & $\begin{array}{l}\text { McClain and others 1997; Lewis and others 2000; Richey and } \\
\text { others 1990; Aitkenhead and McDowell } 2000 .\end{array}$ \\
\hline & POM supply & Moderate & Low & $\begin{array}{l}\text { Finlayson and others 1993; Bass and others 2013; Fellman } \\
\text { and others 2013; Fellman and others } 2014 .\end{array}$ & $\begin{array}{l}\text { Tabacchi and others 2000; Wantzen and others 2008; Boyero } \\
\text { and others } 2015 .\end{array}$ \\
\hline \multirow[t]{2}{*}{$\begin{array}{l}\text { 3. Biotic } \\
\text { movement }\end{array}$} & Interannual variability & Moderate & Moderate & $\begin{array}{l}\text { Townsend and others 1992; Schult and others 2007; Warfe } \\
\text { and others 2011; Novak and others } 2015 .\end{array}$ & $\begin{array}{l}\text { Winemiller and Jepsen 1998; McClain and Naiman 2008; } \\
\text { Power and others } 2008 .\end{array}$ \\
\hline & Primary productivity & Moderate & Unknown & $\begin{array}{l}\text { Petty and Douglas 2010; Warfe and others 2013a; King and } \\
\text { others 2015; Townsend and Padovan } 2005 .\end{array}$ & \\
\hline \multirow[t]{5}{*}{$\begin{array}{l}\text { 4. Food web } \\
\text { structure }\end{array}$} & Trophic resources & Mod-High & Moderate & $\begin{array}{l}\text { Leigh and others 2010; Jardine and others 2012a; 2012b; } \\
\text { Warfe and others 2012a; Blanchette and others 2014. }\end{array}$ & Lewis and others 2001; Zeug and Winemiller 2008. \\
\hline & $\begin{array}{l}\text { Dependence on } \\
\text { floodplain production }\end{array}$ & Mod-High & Moderate & $\begin{array}{l}\text { Bayliss and Yeomans 1990; Madsen and Shine 2000; } \\
\text { Douglas and others 2005; Pettit and others 2011; Jardine } \\
\text { and others 2011; 2013. }\end{array}$ & $\begin{array}{l}\text { Winemiller 1996; Rodriguez and Lewis 1997; Hamilton and } \\
\text { others 1992; Lewis and others 2000; Jepsen and Winemiller } \\
\text { 2002; Thorp and others 2006; Lewis and others } 2001 .\end{array}$ \\
\hline & Habitat provision & High & Moderate & $\begin{array}{l}\text { Pusey and Arthington 2003; Pettit and others 2001; Pettit } \\
\text { and others } 2013 .\end{array}$ & Arrington and others 2005; Pettit and Naiman 2005. \\
\hline & $\begin{array}{l}\text { Food web energy } \\
\text { exchange }\end{array}$ & Moderate & Low & $\begin{array}{l}\text { Pettit and others 2012b; Leigh and others 2010; Davis and } \\
\text { others 2010; Leigh and others } 2012 .\end{array}$ & Sabo and Power 2002; Baxter and others 2005. \\
\hline & $\begin{array}{l}\text { Biogeochemical } \\
\text { linkages }\end{array}$ & Unknown & Low & Fellman and others 2014. & \\
\hline 5. Fire & $\begin{array}{l}\text { Carbon loss, altered } \\
\text { nutrients }\end{array}$ & Unknown & Low & $\begin{array}{l}\text { Gill and others 2000; Pettit and Naiman 2007a; Douglas and } \\
\text { others 2016; Cook 2003; Schmidt and Noack 2000. }\end{array}$ & $\begin{array}{l}\text { Winemiller 1996; Pettit and Naiman 2007; Bond and Keeley } \\
\text { 2005; Certini 2005; van Wilgen and others } 2003 .\end{array}$ \\
\hline 6. Resilience & $\begin{array}{l}\text { Biodiversity, } \\
\text { regeneration }\end{array}$ & Moderate & Moderate & $\begin{array}{l}\text { Jardine and others 2012b; Colloff and Baldwin 2010; Pettit } \\
\text { and others 2012a; Parsons and others } 2009 .\end{array}$ & $\begin{array}{l}\text { Parsons and others 2006; Turton 2012; Gunderson and } \\
\text { Holling 2002; Scheffer and others 2003; Naiman and others } \\
2008 .\end{array}$ \\
\hline
\end{tabular}

yet convincing, or the scale of information collection is not yet sufficient. 3) Low - the uncertainty is high and little information is available. 4) Unknown - no information is available from published studies. 


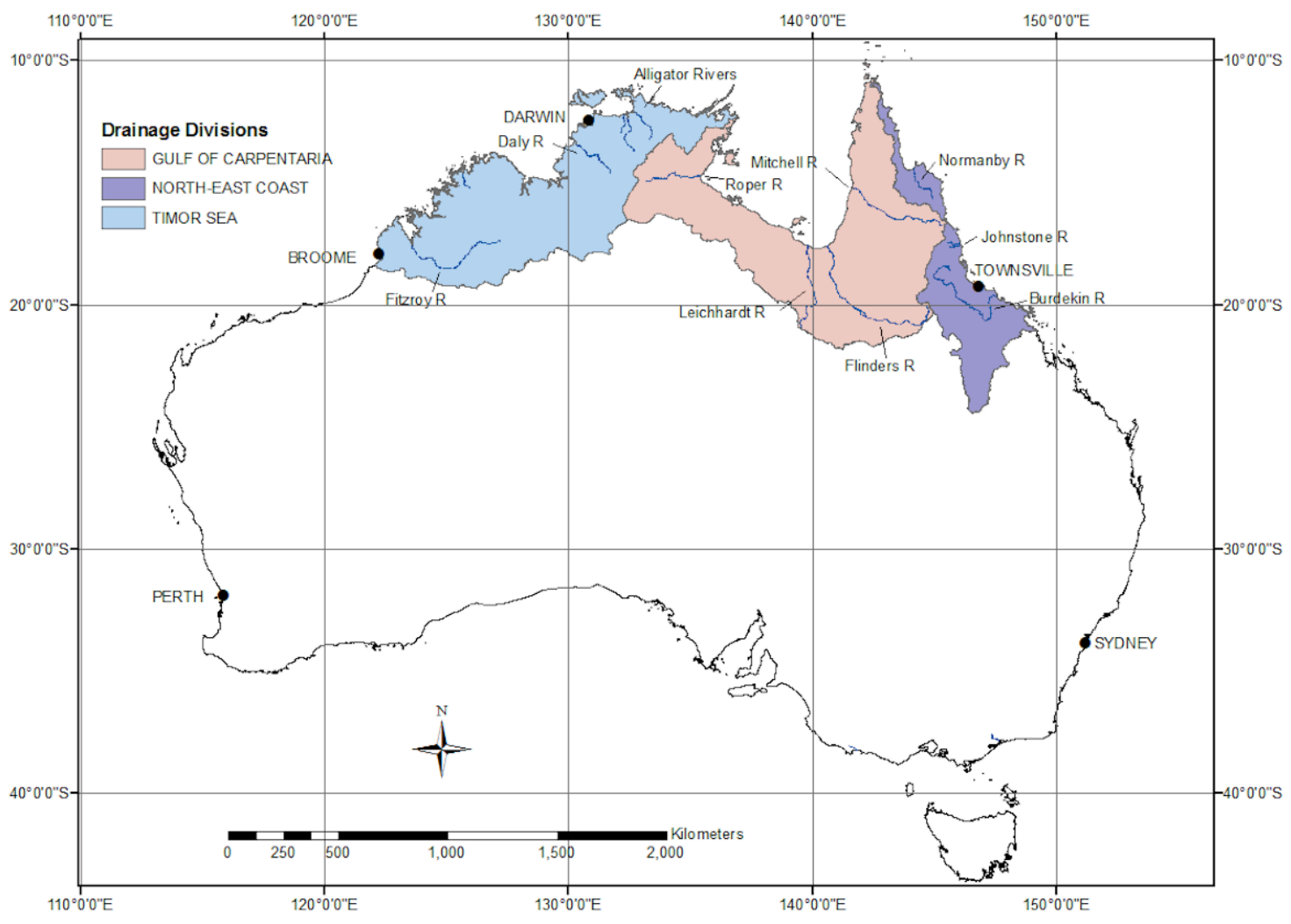

Figure 1. Major drainage divisions in the tropical region of northern Australia are illustrated and the locations of the main rivers mentioned in the text are shown (map produced by D. P. Ward). 

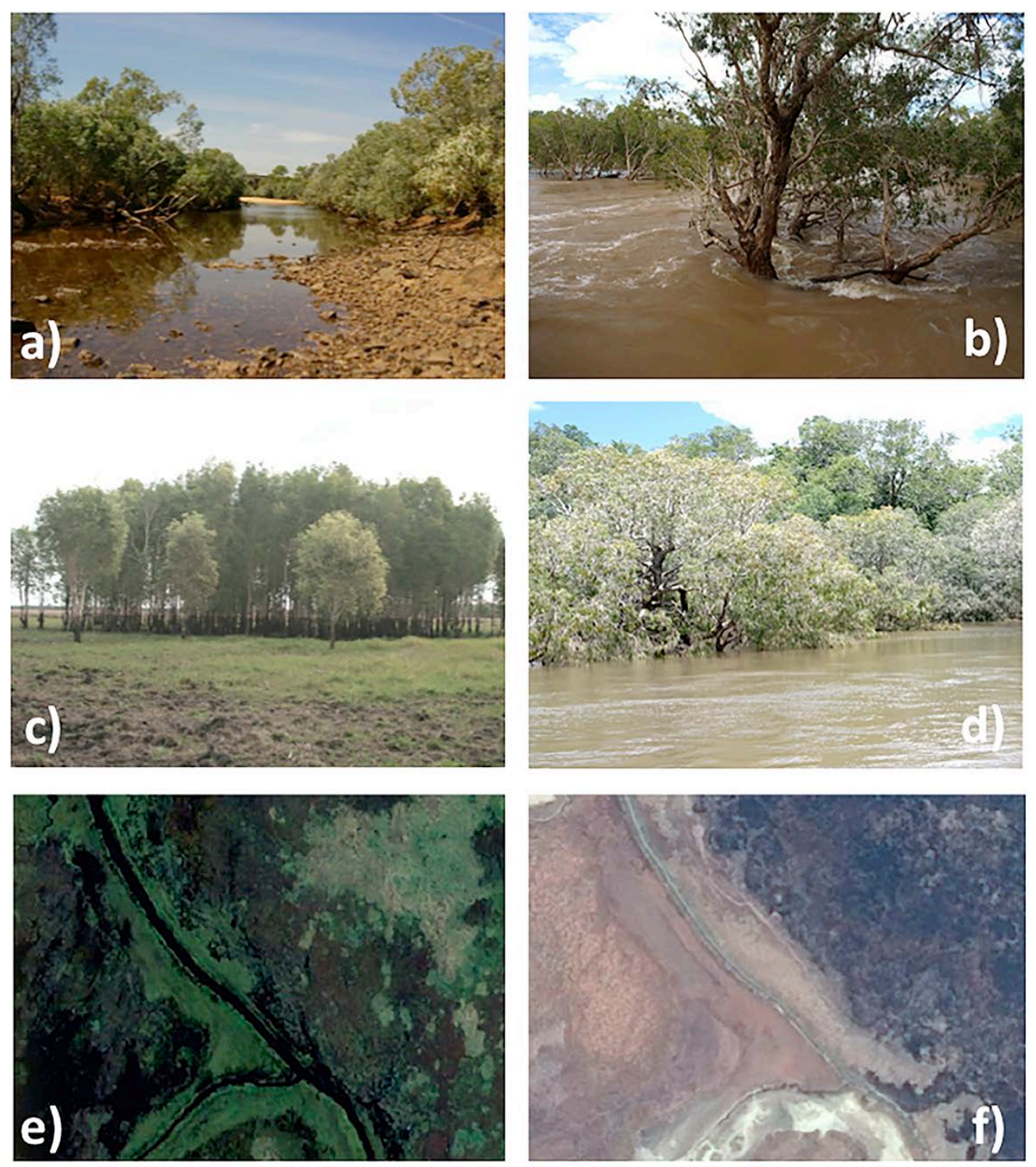

Figure 2: Fergusson River in the Northern Territory, Australia (a) dry season disconnected pools; (b) wet season flood flows. (c) South Alligator River floodplain in the dry season and (d) late wet season. Google Earth images of the Magela Creek floodplain (e) flooded at the end of the wet season (April). Note the extent of floodwaters (dark areas) and flooded vegetation (bright green) and (f) at the end of the dry season (October) with large dry, bare areas of no vegetation and burnt patches in the top right third of the photo. 

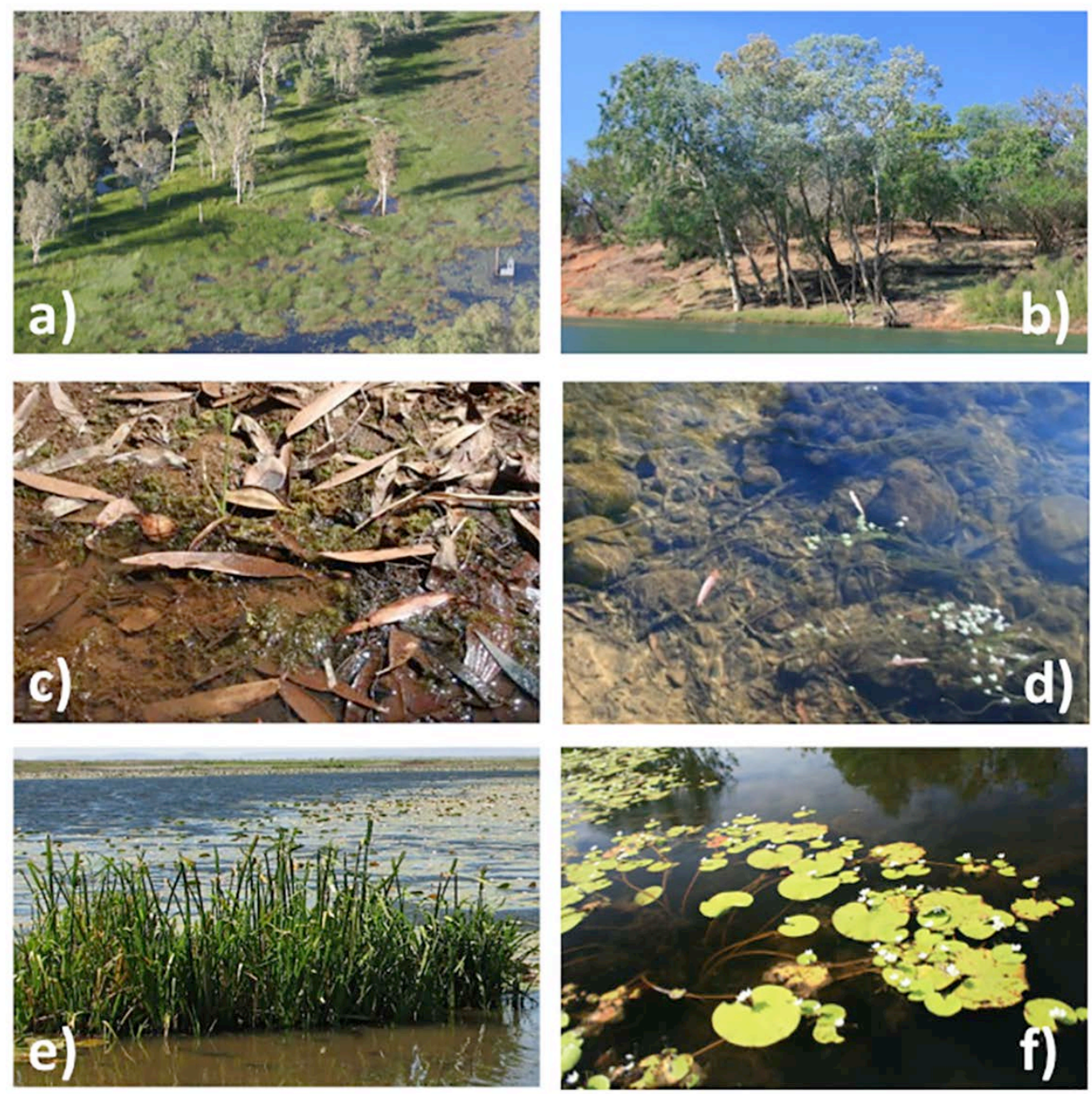

Figure 3: Sources of carbon from primary producers found in riparian and floodplain habitats of tropical Australia. (a) The large plant biomass of aquatic macrophytes and Melaleuca spp trees on the flooded Magela Creek floodplain; (b) Melaleuca argentea, a common riparian tree of northern Australia that like most species in the Myrtaceae family produce leaves high in tannins and other volatile compounds that are not readily decomposed (c) conditioned and decomposition Melaleuca leaves; (d) benthic algae; (e) floodplain emergent macrophyte, Actinoscirpus grossus; (f) Floating, attached aquatic herb, Nymphoides indica. 

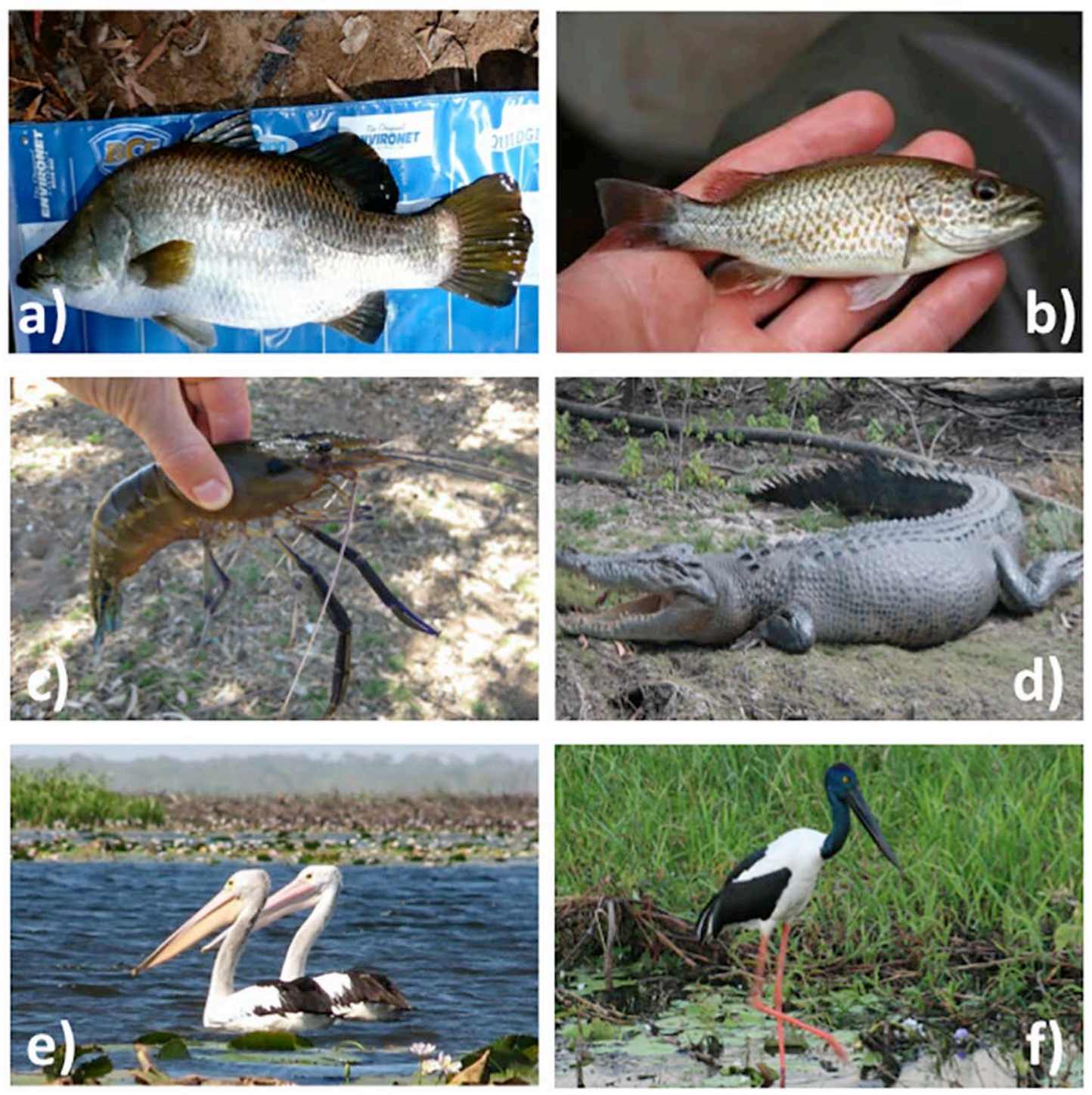

Figure 4: Examples of animals that contribute to the lateral, longitudinal and long distance connectivity of the river and floodplain including, (a) barramundi, Lates calcarifer; (b) terapontid grunter, spangled perch, Leiopotherapon unicolor; (c) palaemonid shrimp, Macrobrachium spinipes; (d) estuarine crocodile, Crocodylus porosus; (e) Australian pelican, Pelecanus conspicillatus; (f) black-necked stork, Ephippiorhynchus asiaticus. 


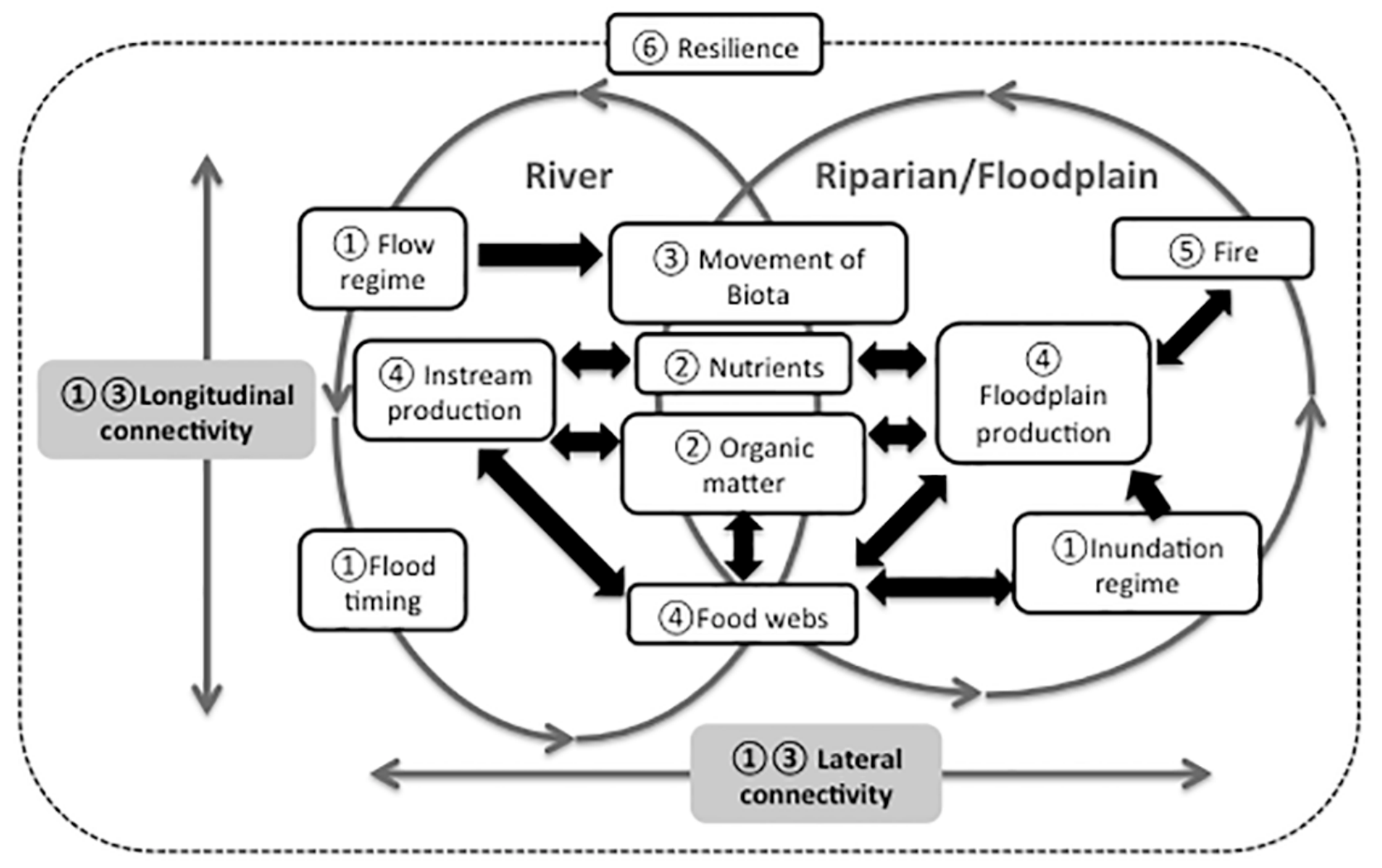

Figure 5. Complexity and connectivity of biogeochemistry and food web components for tropical river floodplain systems summarising the concepts (numbered) discussed in this article. Flow regime (Concept 1 ) including flood timing and inundation patterns are the major drivers of biogeochemical processes of nutrients and organic matter (Concept 2), as well biotic movement both laterally and longitudinally (Concept 3), which in turn influences aquatic food webs and productivity (Concept 4). In riparian and floodplain areas in the wet/dry tropics fire is a major consumer of carbon (Concept 5), as well as an important factor in nutrient redistribution. Natural river/floodplain systems are also likely to have high resilience (Concept 6) to high natural variability in flow regimes 